\title{
Inestabilidad en los monasterios riojanos en el tránsito entre el mundo medieval y moderno ${ }^{1}$
}

\author{
Máximo Diago Hernando ${ }^{2}$
}

Remitido: 28 de noviembre de 2018 / Aceptado: 28 de febrero de 2019

Resumen. El autor estudia la situación de los monasterios de la región castellana de Rioja en la segunda mitad del siglo XV y la primera del siglo XVI. Presta particular atención a aquellos aspectos de la misma que evidencian una grave inestabilidad. En primer lugar da cuenta de la proliferación de disputas por el cargo de abad. Llama la atención sobre la presencia de acciones violentas en dichas disputas. Dedica especial atención a las ocurridas en las primeras décadas del siglo XVI, durante las que se planteó en toda su crudeza el enfrentamiento entre reformadores y conservadores en las comunidades monásticas. Da cuenta de los efectos desestabilizadores que sobre los monasterios tuvieron las injerencias de los miembros de la alta nobleza en esta época. Y valora la intensificación de los conflictos de los monasterios con sus vasallos durante las primeras décadas del siglo XVI. Concluye destacando los contrastes perceptibles en la evolución a largo plazo de los monasterios riojanos, por un lado, y los de otros ámbitos europeos que afrontaron en esta época su disolución, como consecuencia del triunfo de la Reforma protestante, por otro.

Palabras clave: Monasterios; Rioja; Conflictos sociales; Reforma monástica; Siglo XV; Siglo XVI.

\section{[en] Instability in the Monasteries of the Region of Rioja at the End of the Middle Ages and the Beginning of the Modern Age}

\begin{abstract}
The author analyses the situation of the monasteries in the Castilian region of Rioja during the second half of the fifteenth century and the first half of the sixteenth century. He focuses on those aspects that prove the existence of a notorious instability in the monastic communities. In the first place he alludes to the proliferation of disputes for the access to the office of abbot. He pays particular attention to the disputes that took place during the first decades or the sixteenth century, when the confrontation between reformers and conservatives attained its highest level within the monastic communities. He alludes to the destabilizing effects of the interventions of members of the high nobility in the monasteries at this time. He proves that the conflicts between the monasteries and their vassals became more intense during the first decades of the sixteenth century. He concludes highlighting the contrasts that can be perceived in the evolution of the monasteries of Rioja, on one side, and those of other European regions that were dissolved at this time as a consequence of the Reformation, on the other side.
\end{abstract}

Keywords: Monasteries; Rioja; Social conflicts; Monastic reform; Fifteenth century; Sixteenth century.

1 El presente trabajo ha sido realizado en el marco de los siguientes dos proyectos de investigación, de los que es investigadora principal la Dra. Isabel Beceiro Pita: Identidades, contactos, afinidades. La espiritualidad en la Península Ibérica. (Siglos XII-XV) (referencia: HAR2013-45199-R) y Transferencias humanas, culturales e ideológicas entre los reinos ibéricos. Siglos XIII-XV (referencia: HAR 2019-89398-P), ambos financiados por el Gobierno de España.

2 Instituto de Historia, CSIC. maximo.diago@cchs.csic.es ORDIC: 0000-0003-2118-5086. 
Sumario. 1. Introducción. 2. Disputas en el seno de las comunidades monásticas por el acceso a la dignidad abacial durante la segunda mitad del siglo XV. 2.1 Santa María de Nájera. 2.2. San Prudencio de Monte Laturce. 2.3. San Millán de la Cogolla. 3. Violencia en los monasterios en el contexto de la implantación de la reforma observante a principios del siglo XVI. 3.1. San Millán de la Cogolla. 3.2 Santa María de Nájera. 3.3. Sucesos violentos en el señorío del monasterio de San Prudencio: Disputas por el control de la granja de La Noguera 4. Injerencias de la alta nobleza en los monasterios y sus señoríos 4.1. Los Arellano en Santa María de Herce 4.2. Injerencias de los condes de Nieva en el monasterio de Herce 4.3. Presión nobiliaria sobre el monasterio de Santa María de Cañas 5. Intensificación de los conflictos con los vasallos en los señoríos monásticos 5.1. Conflictos antiseñoriales en el abadengo de Santa María de Herce 5.2. Conflictos del monasterio cisterciense de San Prudencio con sus vasallos de Lagunilla 5.3. Resistencia antiseñorial en los lugares del monasterio de Santa María de Cañas 6. Incidencia de la guerra comunera sobre los monasterios 7. Conclusión. 8. Bibliografía.

Cómo citar: Diago Hernando, M. (2019), Inestabilidad en los monasterios riojanos en el tránsito entre el mundo medieval y moderno, 42, 137-180.

\section{Introducción ${ }^{3}$}

El período de tránsito entre la Edad Media y la Edad Moderna fue inusualmente convulso en el conjunto de Europa. Confluyeron en aquellos años conflictos políticos y religiosos de notable envergadura, entre los que cabe destacar la guerra de las Comunidades en la Corona de Castilla, la revuelta de las Germanías en la Corona de Aragón, la guerra de los Campesinos en Alemania, y la introducción y difusión de la Reforma protestante en una parte importante de los territorios del Imperio al norte de los Alpes, desde donde se extendió en las décadas siguientes a otras muchas partes de Europa. Para las comunidades monásticas en particular dicho período resultó muy traumático, y cabría calificarlo como de auténtica encrucijada en la que se decidió su suerte a largo plazo.

El año 1517 representó una fecha clave para el futuro de dichas comunidades. En una parte importante del continente y en Inglaterra, las mismas, tanto masculinas como femeninas, dejaron de existir, pues su supresión fue una de las principales consecuencias de la implantación de la Reforma protestante, aunque el proceso tuvo lugar de forma escalonada ${ }^{4}$. En los territorios que permanecieron bajo obediencia católica, el fenómeno se retrasó hasta finales del siglo XVIII, o hasta comienzos del siglo XIX. Pero también en ellos los monasterios tuvieron que realizar un notable esfuerzo por adaptarse a unas nuevas circunstancias, que les resultaban por lo general bastante más adversas, para garantizarse su supervivencia. Desde este punto de vista, la expansión de la Reforma protestante representó para ellos un revulsivo que llevaría a muchos a tomar conciencia de la necesidad de las reformas, aunque no todos se vieron igualmente afectados por el proceso de renovación.

Así ocurrió, por ejemplo, en la Corona de Castilla, donde el proceso de reforma de las comunidades monásticas, bajo la bandera de la observancia, se había iniciado mucho antes de que Lutero publicase sus célebres 95 tesis en 1517, pero no fue lleva-

3 Abreviaturas: $\mathrm{AChV}=$ Archivo de la Chancillería de Valladolid. AGS $=$ Archivo General de Simancas. AHN = Archivo Histórico Nacional. RE = Registro de Ejecutorias. RGS = Registro General del Sello.

$4 \quad$ Sobre la supresión de los monasterios en Inglaterra (Dissolution) a partir de 1536 pueden consultarse distintas obras de síntesis sobre la Reforma inglesa. Entre otras, la clásica de Dickens, The English, pp. 197-232, y la más actualizada de Jones, The English. Entre las obras de síntesis más recientes sobre la Reforma en el conjunto de Europa, en lengua alemana, cabe destacar Kaufmann, Erlöste und Verdammte. 
do a su conclusión hasta varios años después de esta fecha. No hay que descartar que, de no haberse producido la rápida expansión del protestantismo, las resistencias a la reforma observante se hubiesen continuado prolongando durante bastante más tiempo en los países que permanecieron bajo obediencia católica, entre ellos Castilla.

Para profundizar en el análisis de esta problemática, y abundar en la percepción del contexto de inestabilidad que vivió Europa en el tránsito entre los siglos XV y XVI, nos hemos propuesto en la presente ocasión realizar un trabajo de historia regional, centrado en el análisis de las vicisitudes por las que atravesaron las comunidades monásticas de un espacio concreto de reducidas dimensiones en esta encrucijada decisiva para su futuro. Hemos seleccionado para ello la región de la Rioja, en la Corona de Castilla, aunque muy vinculada con el reino de Navarra, donde varios de sus monasterios tenían fuertes intereses. La razón principal de nuestra elección estriba en que se trata de una región con fuerte impronta monástica, con varias comunidades benedictinas y cistercienses de notable relieve, además de otras pertenecientes a otras órdenes 5 . Proporciona por ello un interesante campo de estudio para la problemática que nos ocupa, que hace posible detectar tendencias y establecer comparaciones.

\section{Disputas en el seno de las comunidades monásticas por el acceso a la dignidad abacial durante la segunda mitad del siglo XV}

En el período anterior a la introducción de las reformas observantes, la dignidad abacial fue muy ambicionada en las comunidades monásticas benedictinas y cistercienses, debido a que tenía carácter vitalicio y además le estaba asignado el usufructo de una parte muy importante del patrimonio monástico, la llamada mesa abacial. Por ello, en períodos de creciente inestabilidad, en las comunidades monásticas y su entorno se multiplicaron y recrudecieron las disputas entre varios candidatos que aspiraban a dicha dignidad en los momentos en que había quedado vacante, bien por muerte del anterior titular o por alguna otra razón, como la renuncia voluntaria del mismo.

\subsection{Santa María de Nájera}

En el monasterio de Santa María de Nájera las disensiones en el seno de la comunidad comenzaron a agravarse a mediados del siglo XV, de la mano del avance del proceso de desvinculación del mismo respecto a su casa matriz borgoñona, el monasterio de Cluny. Así, en 1456, el Papa Calixto III proveyó del priorato a un monje del monasterio de San Millán de la Cogolla, don Gonzalo de Cabredo o de Vergara, que era benedictino, pero no cluniacense. Pero casi al mismo tiempo se efectuó otra

\footnotetext{
En el presente trabajo solo prestaremos atención a los monasterios benedictinos y cistercienses. Para situarlos en el contexto general de la Corona de Castilla puede consultarse, por lo que respecta a los primeros, Linage Conde, San Benito. Cabe precisar que de los tres monasterios benedictinos existentes, uno, el de Santa María de Nájera, fue dependiente de la abadía francesa de Cluny hasta fines del siglo XV. Sobre los monasterios cluniacenses en Castilla en el período más cercano al que vamos a analizar interesa Reglero de la Fuente, Amigos exigentes, e Idem, "Cum reverentia". Por lo que toca a los monasterios del Císter, destaca como visión general, aunque no abarca todo el territorio de la Corona de Castilla, Pérez-Embid, El Císter en Castilla y León.
} 
provisión a favor del prior claustral, Martín Sánchez de Arenzana ${ }^{6}$. Este último no pudo tomar posesión del monasterio, pero, poco tiempo después, cuando el nuevo prior don Gonzalo de Cabredo emprendió un viaje para visitar la villa y priorato de Santa María del Puerto (Santoña), dependiente del monasterio najerense, atentó contra su persona al frente de un grupo de hombres armados. Así se hace constar en el documento otorgado el 2 de marzo de 1458 por el propio don Gonzalo, en el que concedía el perdón a Martín Sánchez de Arenzana, atendiendo la petición que le había efectuado el concejo de Santa María del Puerto y en respuesta a sus muestras de arrepentimiento ${ }^{7}$. Es probable que este enfrentamiento entre los dos candidatos al oficio de prior mayor, que se prolongaría entre 1456 y 1458, fuese el que permaneció en la memoria de las gentes para justificar la declaración contenida en un documento del año 1478, que alude a "cismas, turbaciones y disensiones sobre el priorazgo" que habían sobrevenido en el monasterio najerense en las décadas anteriores ${ }^{8}$.

A la muerte de Gonzalo de Cabredo, en 1486, volvieron a resurgir con fuerza las tensiones en el seno de la comunidad najerense, con ocasión de la designación de su sucesor en el oficio de prior mayor. Nada más producirse su fallecimiento, los monjes procedieron a elegir a uno de ellos, Pablo Martínez de Uruñuela, como nuevo prior, sin esperar a que fuese el abad de Cluny el que lo nombrase en uso de sus prerrogativas. Pero, por contraste con lo que había ocurrido en 1456, en esta ocasión dicho abad no quiso mantenerse al margen y procedió a nombrar como prior a otro monje, Diego Martínez de Garnica. Este último no pudo tomar posesión en el propio monasterio y optó por hacerlo en uno de los establecimientos que este poseía en el reino de Navarra, la ermita de San Adrián de Sangüesa ${ }^{9}$. El designado por los monjes, Pablo Martínez de Uruñuela, para fortalecer su posición, decidió emprender de inmediato viaje a Roma, poco después de que su rival hubiese huido del monasterio najerense ${ }^{10}$. Este último anduvo, de hecho, errante y fugitivo por la comarca buscando apoyos a fin de apoderarse del monasterio y percibir sus rentas. Con el propósito de evitar desórdenes, los reyes le conminaron, sin embargo, a que compareciese ante el Consejo Real en la ciudad de Burgos y presentase allí las bulas en las que fundamentaba sus pretensiones, desestimadas por la parte contraria como falsas $^{11}$. Finalmente Diego de Garnica no pudo imponerse a Pablo Martínez de Uruñuela, el candidato apoyado por los monjes al margen de toda intervención de las autoridades de Cluny. Nada tiene de extraño, por consiguiente, que durante su mandato se acelerase el proceso de desvinculación del monasterio riojano respecto a su matriz borgoñona, que fue llevado a su culminación a principios del XVI, en paralelo con la introducción de la reforma observante y consiguiente incorporación a la Congregación de San Benito de Valladolid.

Diego de Garnica, por otra parte, no fue solo en su monasterio de Santa María de Nájera donde se vio implicado en disputas por el ejercicio del poder y el control de las rentas monásticas. También en la década de 1480 nos consta que llegó a aspirar al gobierno de otro monasterio riojano, paradójicamente no perteneciente a la orden

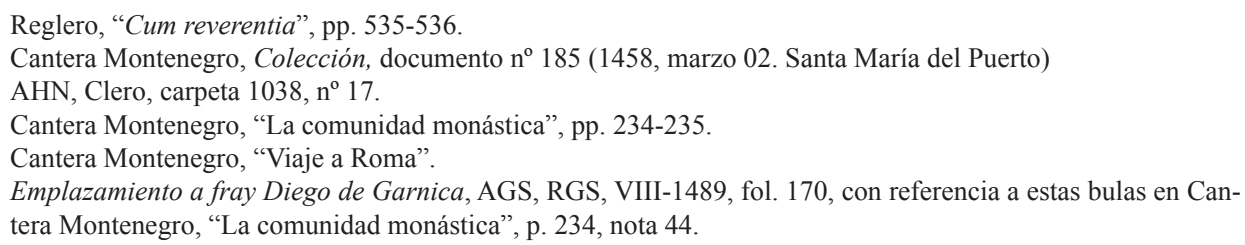


benedictina, en la que él había profesado, sino a la cisterciense. Se trata del de San Prudencio de Monte Laturce, cerca de Clavijo, donde durante la segunda mitad del siglo XV se desataron a su vez graves disputas por el control de la silla abacial, en las que de igual modo que en Santa María de Nájera, también estuvo involucrada la curia romana.

\subsection{San Prudencio de Monte Laturce}

En paralelo con lo que ocurrió en Santa María de Nájera respecto a su casa matriz de Cluny, en el monasterio de San Prudencio también se constata durante la segunda mitad del siglo XV una creciente relajación de las relaciones de dependencia respecto a la abadía de Citeaux, en el obispado de Chalons, basadas en el mecanismo de la filiación que había inspirado todo el sistema organizativo de la Orden del Císter ${ }^{12}$. En contrapartida, se advierte un creciente intervencionismo del poder pontificio en los asuntos internos de este monasterio, que fue de la mano de la colocación del gobierno del mismo en manos de abades que no eran monjes cistercienses y en muchos casos no pertenecían siquiera al clero regular.

Tenemos noticia, en efecto, de que, por motivos que la documentación consultada no nos ha permitido precisar, el abad del monasterio de San Prudencio, don Juan de Cañas, a comienzos de la década de 1460, cedió voluntariamente el gobierno y administración del mismo en manos del papa. Tras aceptar la cesión, este ordenó que un clérigo presbítero de la diócesis calagurritana llamado Pedro Martínez fuese admitido como monje del monasterio, para que una vez recibido y efectuada la profesión, ocupase de inmediato la silla abacial. La voluntad papal no pudo verse finalmente cumplida porque el mencionado Pedro Martínez murió antes de haber podido tomar el hábito. Pero el proyecto pone bien en evidencia cómo se iba desdibujando el perfil cisterciense de la comunidad monástica de San Prudencio, pues desde la lejana Roma se le quiso imponer como abad un individuo que hasta entonces no había pertenecido a la orden, ni podía por tanto estar familiarizado con sus costumbres. Pero no acabaron ahí las irregularidades, pues, tras la muerte de Pedro Martínez, el papa dispuso que el monasterio se entregase en encomienda por tres años a un diácono de la diócesis calagurritana, llamado Juan de Hervias, para que al cabo de dicho tiempo volviese a ser abad del mismo el dimisionario don Juan de Cañas. Parece tratarse de una solución salomónica para la disputa por la abadía que se había desencadendo entre estos dos personajes, respecto a la cual desconocemos muchos detalles. En particular representan para nosotros un enigma las motivaciones de don Juan de Cañas para volver a aspirar a la abadía después de haberla cedido voluntariamente en manos del papa. La designación por la curia romana de un individuo que no era monje cisterciense, sino un simple diácono, para estar al frente del monasterio, aunque solo fuese con carácter temporal, en principio por tres años, evidencia de nuevo la progresiva desvinculación de esta comunidad riojana de la Orden de Císter. En cualquier caso, este diácono no llegó a tener bajo su control efectivo el monasterio, pues el abad dimisionario Juan de Cañas, sin esperar a la resolución del litigio en la curia romana, se apoderó del mismo, para percibir sus frutos y rentas, según denunció el primero ante el papa ${ }^{13}$.

Lekai, The Cistercians, pp. 27-36.

13 García Turza, Documentación, documento no 140 (1464, junio 08. Roma). 
Finalmente, no obstante, unos pocos años más tarde desde Roma se forzó a Juan de Cañas a que renunciase a sus pretensiones, para que en su lugar ocupase la silla abacial un monje del propio monasterio, llamado Pedro de Lezana. Así lo ordenó el papa Pablo II por una bula de 1467, en la que justificaba su decisión en la circunstancia de que Juan de Cañas se encontraba "muy gravado de vejez y años", y no era capaz por ello de soportar cómodamente el peso del gobierno y administración del monasterio. Al mismo tiempo se le prometía, en compensación por su renuncia y méritos, el disfrute de una pensión vitalicia, consistente en la tercera parte de los frutos, rentas y provechos del monasterio, la cual quedaba obligado a hacerle efectiva todos los años el día de San Martín el nuevo abad, Pedro de Lezana, y tras él sus sucesores en el cargo ${ }^{14}$. Contentado con tan jugosas concesiones, fray Juan de Cañas terminaría renunciando, pues en un documento fechado en 1476 se le identifica como abad viejo del monasterio ${ }^{15}$. Nada hemos averiguado, sin embargo, de la suerte de su contrincante, el diácono Juan de Hervias.

Superado este primer episodio de inestabilidad, resultado de las disputas surgidas en torno a la silla abacial de San Prudencio, no pasó mucho tiempo sin que esta volviese a convertirse en motivo de discordia. Ocurrió de nuevo como consecuencia de las injerencias del poder papal, que violentaban los procedimientos contemplados en los ordenamientos del Císter. En efecto, una bula de Inocencio VIII de 1489 nos informa de que, habiendo quedado vacante la abadía tras la muerte de un abad llamado Pedro de Puellas, que habría sucedido a Pedro de Lezana, de nuevo el papa Pablo II decidió poner al frente del monasterio a un individuo que no pertenecía a la Orden del Císter. Según la bula, se trataba de un monje llamado Fernando de Zaratón, que formaba parte de la comunidad de Santa María de Nájera, monasterio benedictino dependiente en aquellos momentos todavía de Cluny. Por razones no precisadas en la bula, este monje cedió después la gracia que se le había hecho en manos del nuevo papa Sixto IV, que accedió a la silla de Pedro en 1471. A partir de aquí las noticias que proporciona el documento, que constituye nuestra única fuente de información, comienzan a resultar confusas. En primer lugar, en él se hace constar que un monje cisterciense llamado Martín de Cirueña había obtenido una provisión del monasterio en su favor efectuada por el abad de la casa matriz de Citeaux, conforme al procedimiento ordinario previsto en la Orden del Císter. Pero el papa Sixto IV, por su parte, ordenó al tesorero de la Iglesia de Calahorra que pusiese como abad al frente del monasterio a nuestro ya conocido Diego de Garnica, pese a que no era monje cisterciense sino cluniacense, como miembro de la comunidad de Santa María de Nájera. Para complicar más aún las cosas, quien controlaba efectivamente el monasterio era un individuo llamado Fernando Martín, contra quien Diego de Garnica presentó un requerimiento ante el tesorero de Calahorra para que fuese removido de su puesto, sin que sepamos a ciencia cierta con qué resultado. Martín de Cirueña, por su parte, apeló ante la sede apostólica, denunciando varios agravios por él sufridos. El papa Sixto IV comisionó para que conociese estas causas a Nicolás de Edum y, tras morir este, al maestro Porres. Antes, sin embargo, de haberse resuelto el litigio, Diego de Garnica renunció a sus derechos en manos del papa. Pero este, en lugar de hacer entrega directamente del monasterio a Martín de Cirueña, que había recibido su nombramiento del abad de Citeaux, trató una vez más de ponerlo en manos de un

\footnotetext{
Ibidem, documento $\mathrm{n}^{\circ} 141$ (1467, agosto 20. Roma).

Ibidem, documento $\mathrm{n}^{\circ} 142$.
} 
individuo que no era cisterciense. En concreto, el candidato al que trató poner en la abadía el papa Inocencio VIII en 1489 era un clérigo llamado Fernando de Fuentes Malo, originario del obispado de Calahorra, aunque aparentemente residente en la curia, pues tenía la condición de portero y familiar del papa ${ }^{16}$. Ciertamente se preveía que antes de ser consagrado como abad tomaría el hábito del Císter, con el que era su intención servir a Dios. Pero hay motivos más que fundados para sospechar que su ingreso en la Orden de San Bernardo constituiría una mera formalidad, y que su verdadera intención era continuar residiendo en Roma, sin dejar por ello de percibir los frutos y rentas de la abadía.

No sabemos con certeza cuál fue el desenlace de este litigio. Sí tenemos constancia, sin embargo, de que Martín de Cirueña consiguió finalmente ocupar la silla abacial de San Prudencio, pues, como comprobaremos más adelante, era abad en 1500, cuando mantuvo un enconado enfrentamiento con los hidalgos de Lagunilla, sus vasallos. Cabe presumir, por tanto, que el clérigo curial Fernando de Fuentes Malo acabase renunciando a sus pretensiones o muriese en el interim. En cualquier caso, los datos aportados, aunque a veces confusos e insuficientes, no dejan lugar a dudas sobre el deterioro de la situación que atravesó este monasterio cisterciense durante la segunda mitad del siglo XV. Su perfil como comunidad del Císter se vio gravemente emborronado por los repetidos intentos de poner a su frente a personas que no habían profesado en dicha Orden y que, en bastantes casos, ni siquiera eran monjes. Son circunstancias que no pueden ser ignoradas a la hora de explicar los esfuerzos de la monarquía castellana por impulsar las iniciativas reformadoras de la congregación observante de la Orden del Císter en Castilla, que afectaron al monasterio de San Prudencio a partir de los primeros años del siglo $\mathrm{XVI}^{17}$.

\subsection{San Millán de la Cogolla}

El monasterio de San Millán de la Cogolla también fue escenario durante la segunda mitad del siglo XV de frecuentes disputas por el control de la comunidad monástica, que, no obstante, en muchos casos, solo conocemos por referencias indirectas no suficientemente explícitas. Por declaraciones de testigos contenidas en documentación de fecha posterior, tenemos noticia de que ya en tiempos del abad Martín de Vergara, que según el padre Joaquín Peña sucedió a su hermano Diego de Vergara en la silla abacial en $1459^{18}$, hubo en el monasterio "çismas e divisiones", que volvieron a resurgir a raíz de que su sucesor, don Juan de Arbolancha, mencionado como abad en una bula de Sixto IV de $1477^{19}$, renunciase la abadía en don Pedro del Castillo ${ }^{20}$. Este último, que recibió su nombramiento del papa Sixto IV en mayo de 1477, es caracterizado por el padre Peña como uno de los abades más insignes de esta casa, que la gobernó hasta su muerte, a finales del año 1500, fundó un arca de misericordia en el Barrionuevo y allanó el camino para la implantación de la reforma en la

16 Bula de Inocencio VIII, dirigida al maestro Guillermo de Porres, capellán y auditor de las causas del palacio apostólico, de 1489, Ibidem, documento $\mathrm{n}^{\circ} 158$. Se publica traducida al castellano, como figura en el becerro en que se nos ha trasmitido.

17 Sobre el proceso de consolidación de la congregación observante del Císter en Castilla, Martín, Los bernardos.

18 Peña, Páginas, pp. 190-191.

19 Ibidem, p.191. Informa este autor que renunció a su dignidad en manos del papa en 1477.

20 Las declaraciones de testigos en documentación conservada en AHN, Clero, leg. 3104. 
comunidad monástica $^{21}$. No obstante, el prolongado período en que ocupó la silla abacial no estuvo exento de dificultades y tensiones. En concreto, por declaraciones de testigos efectuadas muchos años después de los hechos, sabemos que llegó a estar enfrentado con el prior mayor de Nájera, don Gonzalo de Cabredo, y que, por ello, durante algún tiempo el monasterio tuvo que ser guardado y velado ${ }^{22}$. Como ya hemos indicado anteriormente, el mencionado prior mayor, aunque fue puesto al frente de un monasterio cluniacense por el papa Calixto III en 1456, había sido en origen monje de San Millán de la Cogolla. Esta circunstancia contribuiría a explicar sus aspiraciones a hacerse con el gobierno de la comunidad emilianense, sobre las que arroja algó más de luz una provisión que los Reyes Católicos le dirigieron en junio de 1476, a petición del abad y monjes de San Millán de la Cogolla ${ }^{23}$. En ella, en efecto, se reconoce que estos mismos monarcas habían expedido con anterioridad provisiones autorizando a don Gonzalo de Cabredo a que se hiciese cargo de la administración del monasterio de San Millán, como había solicitado, argumentando que el abad era una persona demasiado anciana y con dolencias para hacerse cargo personalmente del gobierno del monasterio, sus vasallos y bienes. El documento no identifica por su nombre a dicho abad, pero cabe presumir que se tratase de Juan de Arbolancha. En cualquier caso, lo cierto es que desde la comunidad emilianense se reaccionó en contra de esta disposición de los reyes, argumentando que, admitiendo que el abad estuviese impedido, había personas en el monasterio que lo podían regir y administrar, por lo que no se precisaba que viniese nadie de fuera a hacerlo. Y los reyes atendieron este argumento, ordenando por esta nueva provisión al prior mayor de Nájera que no se entrometiese a entender en la administración de San Millán de la Cogolla, salvo en el caso de que tuviese poder para ello de quien canónicamente lo pudiese dar.

Parece bastante probable, por consiguiente, que en aquellos momentos hubiese planteado un conflicto entre Gonzalo de Cabredo y Pedro del Castillo por el control del monasterio emilianense, que en parte pudo verse influenciado por los enfrentamientos entre partidarios de Isabel la Católica y su sobrina la princesa Juana por la sucesión al trono. De ahí las decisiones contradictorias que los reyes tomaron al respecto, encomendando primero la administración del monasterio al prior de Nájera para retirársela poco después. No fue el único bandazo que dieron en este convulso período de su reinado a la hora de tomar decisiones que afectaban al cenobio riojano. Lo demuestra que, en ese mismo mes de junio de 1476, ordenaron a esta comunidad benedictina y a sus vasallos que se pusiesen de nuevo bajo la encomienda de Álvaro de Estúñiga, duque de Béjar, pese a que pocos meses antes se les había ordenado que no lo tuviesen más como encomendero, porque había apoyado a la princesa Juana y al rey de Portugal en la guerra ${ }^{24}$.

Tras este episodio de disputa por el control del monasterio, al año siguiente, en 1477, Pedro del Castillo sería entronizado como nuevo abad en sustitución del anciano e impedido Juan de Arbolancha y la situación terminaría normalizándose. No obstante, las tensiones no desaparecieron del seno de la comunidad monástica. Un factor que contribuyó a desencadenarlas fue el propósito de este abad de implantar

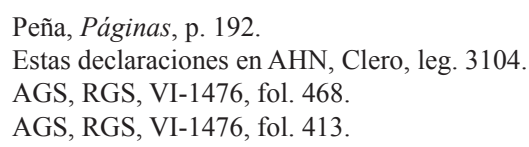


la reforma de las costumbres en el seno de la misma. Era solo un primer paso en el proceso de implantación de la observancia según el modelo de San Benito de Valladolid, pues no hay constancia de que Pedro del Castillo diese ningún paso para la supresión del carácter vitalicio del cargo abacial. Lo que nos interesa aquí destacar, en cualquier caso, es que sus afanes reformistas, por limitados que fuesen, suscitaron oposición entre algunos de los monjes sometidos a su autoridad, contrarios al endurecimiento de las costumbres de vida que exigía la reforma, y acabaron provocando una situación de inestabilidad. Así lo denunció el propio Pedro del Castillo ante la monarquía en 1489, al solicitar el auxilio del brazo real. Se lamentó en concreto de que varios monjes que habían consentido en la reforma, poco después habían huido del monasterio, y andaban por la comarca "apóstatas" y "fuera de la regla", perpetrando "cosas indebidas". Y, aunque el abad quería proceder contra ellos conforme a la regla y constituciones de la orden, no podía hacerlo de forma eficaz, porque los díscolos monjes recibían el apoyo de caballeros y otras personas del entorno ${ }^{25}$.

En resumen, por lo tanto, la segunda mitad del siglo XV se caracterizó en las principales comunidades monásticas de la Rioja por un incremento significativo de la inestabilidad, fruto de las descarnadas disputas por el acceso a las abadías, que tenían carácter vitalicio y proporcionaban abundantes ingresos. Las crecientes injerencias de la curia romana en el gobierno de los monasterios, con fines a veces espúreos, cuando el móvil principal era premiar a clérigos curiales de muy diverso rango, contribuyeron a exacerbar esta situación. Como resultado, los monasterios perdieron progresivamente su perfil tradicional, conforme se percibe sobre todo en el caso de los cluniacenses y cistercienses, que cada vez se distanciaron más de sus casas matrices en Francia. En consecuencia, se fue percibiendo de forma cada vez más nítida la necesidad de someter a estas comunidades a una radical reforma, que las pusiese a salvo del desprestigio que pudiese justificar una eventual disolución. Los Reyes Católicos, tras su consolidación en el trono, tomaron plena conciencia de esta necesidad y se emplearon a fondo en esta empresa ${ }^{26}$. Pero con ello contribuyeron también indirectamente a prolongar la inestabilidad durante unas cuantas décadas, las primeras del siglo XVI, porque el avance de la reforma no se pudo lograr sin hacer frente a enconadas resistencias, que con frecuencia se manifestaron de forma violenta, según comprobaremos en el siguiente apartado.

\section{Violencia en los monasterios en el contexto de la implantación de la reforma observante a principios del siglo XVI}

El proceso de introducción de la reforma observante en los monasterios benedictinos y cistercienses de la Rioja a partir del reinado de los Reyes Católicos ya ha sido objeto de estudios monográficos ${ }^{27}$, que han llamado la atención sobre la participación en el proceso de los principales miembros de la alta nobleza en la región, en paralelo a lo que ocurrió en otras comarcas septentrionales del reino de Castilla con fuerte presencia monástica ${ }^{28}$. Para evitar reiteraciones, nos limitaremos aquí a ana-

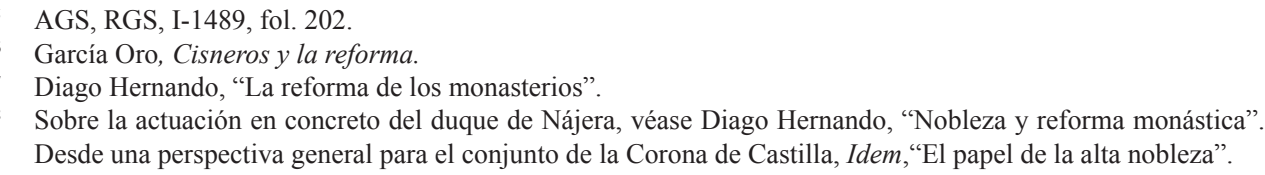


lizar las manifestaciones violentas que tuvo dicho proceso en las primeras décadas del siglo XVI como consecuencia del enfrentamiento entre monjes reformados y monjes de perfil conservador, opuestos a la reforma, que arrastró a numerosos laicos de la comarca, y sembró la inestabilidad y el desorden en las comunidades monásticas. Prestaremos atención, por consiguiente, a sucesos que ponen bien de relieve hasta qué punto estas comunidades estaban imbricadas en la vida política regional, que no eran percibidas como meros centros espirituales, sino como auténticos polos para el ejercicio del poder. Buena prueba de ello es que los propios edificios de los monasterios de San Millán de la Cogolla y Santa María de Nájera fueron escenario de acciones de carácter militar, en las que participaron numerosos laicos armados, pese al carácter evidentemente sacrílego de las mismas. Y estos mismos edificios fueron puestos bajo su control por oficiales laicos de la monarquía, haciendo uso de la fuerza contra quienes les opusieron resistencia, los cuales los mantuvieron bajo su gobierno y administración durante muchos meses.

Los brotes de violencia se iniciaron ya en vida de la reina Isabel la Católica, si bien fue tras su muerte, en noviembre de 1504, cuando encontraron un caldo de cultivo más propicio, dado que el debilitamiento de las instituciones de gobierno de la monarquía, provocado por la crisis sucesoria, favoreció la proliferación de desórdenes y la radicalización de los conflictos en todos los ámbitos locales y regionales del reino.

\subsection{San Millán de la Cogolla}

En el caso del monasterio benedictino de San Milán de la Cogolla, el período de las turbulencias se inició tras la muerte de su último abad perpetuo, Pedro del Castillo, ocurrida hacia diciembre de 1500. Se desencadenó entonces una virulenta disputa entre dos candidatos que alegaron su derecho exclusivo al desempeño del oficio de abad. Por un lado, fray Juan de Soria, comprometido con la implantación de la reforma observante en el monasterio. Y, por el otro lado, fray Pedro de Salazar, prior claustral, que encabezó la oposición a dicha reforma y aspiró a ocupar la silla abacial con carácter vitalicio, oponiéndose además a las novedades que llevaba consigo la implantación de la observancia ${ }^{29}$.

La elección como abad de fray Juan de Soria fue auspiciada por el propio abad de San Benito de Valladolid, que consiguió que este monje, perteneciente a la familia hidalga soriana de los Morales, fuese designado como abad trienal. Y para que dicho cambio en el perfil institucional del cargo abacial fuese firme se iniciaron inmediatamente los trámites para suplicar al papa que expidiese las bulas confirmatorias de dicha elección. El abad de Valladolid, no obstante, era consciente de que existía una fuerte oposición en determinados sectores de la comunidad monástica emilianense a estos cambios. Y por ello, a los pocos días, solicitó a los reyes una carta de seguro, con el argumento de que se recelaba de que algunas personas tratarían de despojar por la fuerza a fray Juan de Soria de la abadía ${ }^{30}$. Y, efectivamente, después de haberse llevado a cabo su elección, en un jueves 13 de febrero de 1501, fray Pedro de Salazar, con la declarada intención de impedir que saliese adelante la implantación de la

\footnotetext{
29 Sobre la resistencia a la reforma observante de Pedro de Salazar, a quien ya en 1497 se ofreció una renta vitalicia a cambio de que la apoyase, véase Diago Hernando, "La reforma de los monasterios", p. 672.

30 AGS, RGS, I-1501, fol. 23.
} 
reforma observante en la comunidad y hacerse él personalmente con el control de la abadía, reunió en torno a sí a varios monjes que procedieron a elegirle como abad perpetuo. Acto seguido, estos monjes se dirigieron al "palacio" donde se encontraba fray Juan de Soria y los demás monjes que acataban su autoridad, quebrantaron las puertas de entrada, expulsaron a todos los que allí se encontraban, y se apoderaron por la fuerza de todo el edificio monástico, en el que metieron en torno a dos centenares de hombres legos armados ${ }^{31}$.

Resulta digno de notar que, ante estos hechos violentos de naturaleza sacrílega, se produjo una reacción espontánea de un sector de la sociedad política laica de la comarca, aglutinado en torno al concejo de la ciudad realenga de Santo Domingo de la Calzada, que decidió intervenir directamente por su propia iniciativa, sin haber recibido previamente mandato alguno de los reyes. En efecto, dicho concejo, al tener noticia de que en el monasterio se había producido cierto ayuntamiento de gentes "en asonadas y alborotos sobre la elección del abad", procedió a reunirse en asamblea. En ella se decidió que "por excusar los escándalos y muertes de hombres y otros daños que sobre ello se podrían seguir y recrescer", el alcalde de la ciudad, bachiller Diego Álvarez de Calahorra, fuese al monasterio al frente de un contingente de gente armada. Así lo hizo, procediendo a dispersar a los laicos que se habían apoderado del edificio monástico, "desencastillándolo" y colocándolo bajo su mando, en espera de que los reyes ordenasen lo que se había de hacer ${ }^{32}$.

No obstante, la versión de los hechos ofrecida por los representantes de Santo Domingo de la Calzada resulta en algunos aspectos sospechosa, al transmitir una imagen de unanimidad en el apoyo a los observantes que aparentemente no se dio. Por el contrario, nos consta que algunos vecinos de esta ciudad fueron condenados por haber estado entre los que contribuyeron a encastillar el monasterio y, por lo tanto, cabe sospechar que prestaron su apoyo a los monjes claustrales. Sería el caso, por ejemplo, del bachiller Juan de Oña, quien fue arrestado y condenado a una multa de 20.000 mrs. y a destierro, por habérsele encontrado culpable de participar en el encastillamiento de San Millán ${ }^{33}$. Incluso el propio alcalde de Santo Domingo de la Calzada, el bachiller Álvarez de Calahorra, quien encabezó la fuerza armada que en nombre del concejo acudió a desencastillar el monasterio, nos consta que con posterioridad fue arrestado por un oficial del rey enviado como pesquisidor, el corregidor de Burgos, García de Cotes, quien lo mantenía preso en julio de $1501^{34}$. No debía entender por tanto este comisionado regio que el referido alcalde había actuado como liberador de la comunidad monástica y en especial de los monjes observantes recientemente incorporados a la misma. Más bien, al contrario, parece más plausible que lo considerase sospechoso de haber apoyado a los monjes claustrales encabezados por fray Pedro de Salazar, aunque sorprende que, de ser esto cierto, el concejo de Santo Domingo de la Calzada reclamase después que se le indemnizase por los

31 Esta reconstrucción de los hechos es la ofrecida por fray Martín de Vergara, monje de San Millán enviado a la corte en representación del abad de San Benito de Valladolid y de fray Juan de Soria. Se recoge en AGS, RGS, II-1501, fol. 260.

32 AGS, RGS, III-1501, fol. 497.

33 Cédula de los Reyes Católicos, dirigida a García de Cotes, corregidor de Burgos, para que reexamine la causa del bachiller Juan de Oña, vecino de Santo Domingo, condenado por dicho corregidor, y que alega que es inocente, pues no se encontró en el "encastillamiento” al tiempo que se hizo, AGS, Cámara de Castilla, Cédulas, 5, 141,1 (1501, junio 07).

34 Provisión a García de Cotes, corregidor de Burgos, a petición del bachiller Diego Álvarez de Calahorra, AGS, RGS, VII-1501, fol. 289. 
gastos en que había incurrido con motivo de la expedición organizada al monasterio al mando de este individuo.

Sea como fuere, de lo que no hay duda es de que esta expedición armada organizada por el referido concejo no fue la que devolvió la normalidad al monasterio de San Millán. Por el contrario, tenemos constancia de que durante los meses de febrero y marzo de 1501 se decidió desde la corte el envío de dos sucesivos jueces pesquisidores, ambos con la misión de desencastillar el edificio monástico, y de devolver el control sobre el mismo a los monjes observantes y al nuevo abad legítimamente elegido, fray Juan de Soria. El primero de estos comisionados regios fue el bachiller Pedro Ordóñez de Pampliega, al que se nombró por real provisión de febrero de 1501, con un salario de 230 mrs. por día ${ }^{35}$, al cual se le concedió en el mes de marzo una prórroga de otros veinte días para completar la misión ${ }^{36}$. No sabemos apenas nada sobre su actuación, pero no debió dar mucho resultado, pues pocos días después recibió una comisión semejante el corregidor de Burgos, García de Cotes, a quien, no obstante, se le asignó un salario muy inferior, de solo $150 \mathrm{mrs}$ por día ${ }^{37}$. Al bachiller Pedro Ordóñez de Pampliega se le volvió a comisionar de nuevo en el mes de abril para que conociese sobre una nueva denuncia presentada por el abad de San Benito de Valladolid, quien había reclamado la devolución de la plata, ornamentos y otras cosas que ciertas personas se habían llevado del monasterio cuando había estado encastillado $^{38}$. Pero tampoco tenemos noticias de actuaciones suyas en relación a este asunto, por lo que todo indica que el principal responsable del restablecimiento del orden en el monasterio fue el mencionado corregidor de Burgos, quien, como hemos adelantado, actuó contra varios vecinos de Santo Domingo de la Calzada de incuestionable relieve político.

Con el apoyo de este oficial regio, fray Juan de Soria conseguiría finalmente imponerse a fray Pedro de Salazar, y los observantes se harían con el control del monasterio. Pero no duró mucho tiempo la calma en la comunidad monástica emilianense, porque muy pronto surgió otro encarnizado enfrentamiento entre dos facciones que se disputaron su control, que contaron con el apoyo respectivo de dos de los más poderosos nobles de la región, el condestable de Castilla, del linaje Velasco, por un lado, y el duque de Nájera, del linaje Manrique, por otro. Esta evolución de los acontecimientos fue desencadenada por la pérdida, por parte de fray Juan de Soria, de la confianza que le había dispensado el principal promotor de la reforma observante, el abad de San Benito de Valladolid, quien en su lugar puso, al frente del monasterio de San Millán, para que llevase adelante la implantación de dicha reforma, a un monje de origen navarro llamado fray Miguel de Alzaga. Las razones por las que se produjo la ruptura entre fray Juan de Soria y el abad vallisoletano no resultan claras, pero es seguro que el mencionado monje de origen soriano se ausentó de San Millán y terminó siendo encerrado como prisionero en una torre del monasterio de San Salvador de Oña por mandado de los reformadores observantes de la Orden de San Benito. Paralelamente se produjo la toma del control del monasterio riojano por fray Miguel de Alzaga, quien desde el primer momento hubo de hacer frente a la encarnizada oposición del duque de Nájera, que se movilizó para que fray Juan

\footnotetext{
AGS, RGS, II-1501, fol. 260.

AGS, RGS, III-1501, fol. 390 .

AGS, RGS, III-1501, fol. 40.

AGS, RGS, IV-1501, fol. 25.
} 
de Soria fuese liberado y puesto de nuevo al frente de dicha comunidad monástica ${ }^{39}$. El duque no dudó en recurrir al ejercicio de la fuerza para combatir a fray Miguel de Alzaga, al que consideraba su principal enemigo ${ }^{40}$. Y, en efecto, a principios del año 1507 reunió cerca de dos mil hombres de armas con los que sometió a cerco al monasterio de San Millán, aunque no llegó a tomarlo ${ }^{41}$. Además presionó de forma violenta a los vasallos de dicho monasterio para que no le entregasen las rentas que le debían como señor ${ }^{42}$.

Para poner freno a estas actuaciones violentas del duque, la monarquía envió de inmediato a un juez pesquisidor, el licenciado Bermúdez, lo que no fue del agrado del díscolo noble, que lo denunció por favorecer abiertamente en sus actuaciones los intereses del condestable en detrimento de los suyos ${ }^{43}$. De hecho, la llegada de este comisionado regio favorecería la consolidación de la posición de fray Miguel de Alzaga al frente de la comunidad monástica emilianense, que pudo prolongarse durante muchos meses pese a la encarnizada resistencia del duque de Nájera, aunque también, en gran parte, debido al apoyo que le prestaba el condestable.

Las maniobras del monje navarro para perpetuarse como abad vitalicio -para lo cual consiguió incluso bulas del Papa Julio II en marzo de 1510, en las que se restablecía el carácter perpetuo del cargo abacial en este monasterio riojanodieron, sin embargo, pronto un vuelco a la situación, por cuanto los reformadores observantes dejaron de apoyarle y, como consecuencia, perdió también el apoyo de la monarquía del que se había beneficiado inicialmente. En efecto, nada más tener conocimiento de la obtención de estas bulas por el monje navarro, el abad de San Benito de Valladolid se desplazó en persona al monasterio de San Millán, acompañado por dos oficiales de la monarquía, el licenciado Francisco Galindo y el escribano Antonio del Corral, para impedir que lo dispuesto en dichas bulas

39 Sobre el perfil político del primer duque de Nájera, véase Montero Tejada, "Violencia y abusos". Sobre sus intervenciones en el proceso de reforma de los monasterios riojanos Diago Hernando, "Nobleza y reforma monástica". Sobre sus enfrentamientos banderizos con la casa de Velasco, puestos en relación con la guerra civil en Navarra, Idem, "Las comarcas castellanas".

40 Al margen de la vinculación de fray Miguel de Alzaga a los Velasco y a los agramonteses, también se han barajado otros motivos para explicar la gran enemistad existente entre él y el duque de Nájera. En concreto, sobre esta cuestión, Guinea y Lerena recoge declaraciones de testigos manifestando que este abad había mantenido pleitos con el duque porque había mandado derribar casas y palacios que el monasterio poseía en Badarán, y había obligado a los vasallos del monasterio a llevar sus ganados a la ciudad de Nájera para destinarlos al aprovisionamiento de su casa (Señores de la guerra, pp. 177-179). Joaquín Peña, por su parte, alude a una actuación contra el duque que había tenido lugar por iniciativa del licenciado Alonso Bermúdez, pesquisidor enviado a petición de fray Miguel de Alzaga cuando era mayordomo del monasterio. Ante este juez se denunció que un alguacil del duque y cuatro lacayos suyos habían ido a Tricio y expulsado de la casa que allí poseía el monasterio a las personas puestas por el abad, llevándose todo el vino que había en la bodega. El pesquisidor los emplazó, pero no comparecieron ante él, y fueron condenados en rebeldía a penas de destierro y de servicio en el presidio de Mazalquivir. Por su parte el propio duque fue condenado a restituir al monasterio 340 cántaras de vino (Peña, Páginas, p. 197).

41 Comisión al corregidor de Logroño para que acuda a levantar el cerco al monasterio de San Millán, y dispersar a los hombres de armas reunidos por el duque. La cifra de dos mil hombres es la que figura en el documento, pero debe tratarse de una estimación deliberadamente exagerada, AGS, RGS, II-1507.

42 Carta de seguro para los vasallos del monasterio de San Millán, que se temían del duque de Nájera, AGS, RGS, VII-1507.

43 AGS, Cámara-Personas, leg. 19. En dicho memorial del año 1507, redactado por el procurador del duque de Nájera, se acusa al dicho juez de que "en las cosas que el Consejo Real le ha comisionado tocantes al duque y su tierra y encomiendas (...) se ha mostrado parte formada por el condestable y sus valedores, mandando prender en las tierras del duque los hombres, y tomarles sus bienes de noche con gentes del condestable. Ha mostrado tener mala voluntad al duque". 
se llevase a ejecución y se pusiese en peligro la implantación de la observancia en la comunidad emilianense. Al personarse estos ante las puertas del monasterio, un tal Pablo de Cueva las cerró y les impidió la entrada, argumentando que él era tenedor del monasterio por doña Juana de Aragón, esposa del condestable Bernardino Fernández de Velasco ${ }^{44}$. Fue el último acto de resistencia importante que fray Miguel de Alzaga pudo oponer al imparable avance de la maquinaria de la monarquía a favor de la implantación de la observancia, pese a que el monje navarro, para fortalecer su posición, había hecho venir al monasterio en torno a setenta hombres armados desde su reino de origen. El licenciado Galindo terminó apoderándose del edificio monástico, que acto seguido dejó a cargo del alguacil Alonso de Salinas, para él por su parte, como veremos, centrarse en la tarea del gobierno y administración del monasterio de Nájera. Este alguacil, por otro lado, permaneció apoderado del edificio de San Millán durante 263 días, empleado en la tarea de restablecer el orden a fin de posibilitar que siguiese adelante el proceso de implantación de la observancia ${ }^{45}$.

Para cuando los comisionados regios se apoderaron del edificio monástico, fray Miguel de Alzaga ya había logrado huir, para ponerse a salvo en Navarra, donde contaba con apoyos en el bando agramontés. Pero al año siguiente, en 1511, allí terminó encontrando la muerte, víctima de un altercado violento, del que, según fundadas sospechas, cabe considerar como principal responsable a su visceral enemigo, el duque de Nájera, quien no habría dejado de mover hilos hasta asegurarse su definitiva aniquilación ${ }^{46}$. En cualquier caso, no fue el duque el único que persiguió con encarnizamiento a este controvertido monje, quien, en un primer momento, había sido campeón de la causa observante, para luego traicionarla con sus maniobras en Roma. También lo hizo la propia monarquía, representada en la persona del regente, Fernando el Católico, quien terminó tratándolo como a un auténtico delincuente, dando instrucciones a todos los oficiales a su servicio para que averiguasen el paradero del abad fugitivo, impidiesen a toda costa que traspasase la frontera para refugiarse en Navarra y, en caso de llegar a localizarlo, lo mantuviesen detenido hasta recibir nuevas instrucciones ${ }^{47}$. Este interés por lograr la detención de fray Miguel de Alzaga evidencia el compromiso del Rey Católico por asegurar el éxito en la implantación de la reforma observante en los principales monasterios benedictinos de Castilla, para el que el intrigante monje navarro representaba un evidente peligro. Pero, sin duda, estaba además inspirado por motivos esencialmente políticos, relacionados con la militancia del monje navarro en el bando agramontés, en unos momentos en

44 Peña, Páginas, p. 195.

45 García Oro y Portela Silva, Los monasterios, docs. 171, 172 y 173. Según memorial dirigido por el alguacil Alonso de Salinas al presidente del Consejo Real, él llegó al monasterio el 3 de noviembre de 1510 (AGS, Cámara-Pueblos, leg. 17, San Millán).

46 Años más tarde, el obispo de Calahorra, Juan de Velasco, acusó al duque de Nájera de haber amparado en Nájera a un clérigo presbítero llamado Joanes de Aguilar, que había espiado a fray Miguel de Alzaga para que lo matasen (AGS, Consejo Real, leg 27, fol. 9). Por su parte, Guinea y Lerena recoge declaraciones de testigos que sostuvieron que el duque había mandado matar a fray Miguel de Alzaga, abad de San Millán, "porque denunciaba sus crueldades y sus excesos" (Señores de la guerra, pp. 177-179).

47 Cedulas de Fernando el Católico, suscritas por el secretario Miguel Pérez de Almazán, AGS, Cámara-Cédulas, 7, 3, 4 (1510, octubre 28). Dirigidas respectivamente a Juan de Silva, capitán general de la frontera de Navarra "y sus comarcas", al corregidor de Guipúzcoa, al alcaide de Salsas, al arzobispo de Zaragoza, al lugarteniente de Cataluña y al gobernador de Rosellón. 
que se estaba fraguando el proyecto de conquista de Navarra por Fernando, apoyado en el bando beamontés, en el que también militaba el duque de Nájera ${ }^{48}$.

\subsection{Santa María de Nájera}

La reforma observante se había comenzado a introducir en Santa María de Nájera algo más tarde que en San Millán, por virtud de una concordia firmada en 1503 con el último abad perpetuo, don Pablo Martínez de Uruñuela, bajo los auspicios de la monarquía. El propio duque de Nájera, por encargo de la reina Isabel la Católica, quedó entonces como garante de que las condiciones estipuladas en la misma serían respetadas. A los pocos meses de la muerte de la reina, se produjo, sin embargo, la ruptura entre los monjes conventuales, encabezados por don Pablo de Uruñuela, y los observantes, que fue justificada por el duque con el argumento de que estos últimos no habían respetado las condiciones de la concordia. En concreto, reprochó al abad de San Benito de Valladolid el haber querido poner a fray Miguel de Alzaga, su más encarnizado enemigo, al frente el monasterio najerense ${ }^{49}$.

En aquella tesitura los monjes conventuales actuaron con rapidez y, gracias a la acción combinada del licenciado de la Canal y de Fernando Marín, laico sobrino de don Pablo de Uruñuela, quien había conseguido en Roma una bula de Julio II, por la que se le entregaba en encomienda la abadía que había renunciado su tío en manos del Papa, se hicieron por la fuerza, en el año 1506, con el control del monasterio ${ }^{50}$. Al mismo tiempo, apresaron a varios monjes observantes que habían sido introducidos en la comunidad en los meses antecedentes para promover su reforma.

Son varios los indicios que llevan a sospechar que esta acción armada tuvo lugar con el apoyo explícito del duque de Nájera, aunque este lo negara. Entre ellos destaca el hecho de que Fernando Marín durante los meses en que estuvo apoderado del monasterio prestó apoyo militar al duque en sus intervenciones en el reino de Navarra a favor de los beamonteses, echando mano para ello de los propios vasallos del monasterio, como denunciaron, por ejemplo, los vecinos de Torrecilla de Cameros ${ }^{51}$. Su entrada violenta en el monasterio de Nájera se produjo en un momento en el que las instituciones de gobierno central de la monarquía se encontraban muy debilitadas como consecuencia del conflicto sucesorio, y ello facilitó el éxito de su empresa. El regreso a Castilla de Fernando el Católico fue seguido, sin embargo, de un inmediato reforzamiento de dichas instituciones, que volvieron a emplearse a fondo para llevar a conclusión el proceso de implantación de la reforma observante en los monasterios

48 Diago Hernando, "Las comarcas castellanas".

49 Memorial dirigido por el duque de Nájera al Consejo Real, en García Oro y Portela Silva, Los monasterios, doc. 42. También aportan informaciones de interés sobre el proceso Ibidem, docs. 20 y 25.

50 Sobre las diligencias en Roma de Pablo Martínez de Uruñuela y su sobrino Fernando Marín para conseguir la abadía de Nájera, arrebatándola a los observantes de San Benito de Valladolid, véase Diago Hernando, "La reforma de los monasterios”, pp. 678-679. Además de la documentación ahí mencionada interesa un breve de Julio II de 9 de diciembre de 1507 dirigido al cardenal Cisneros, para que el abad de San Benito de Valladolid no estorbase a Fernando Marín, nombrado abad comendatario de Santa María de Nájera, en la posesión de dicho monasterio (AHN, Universidades, carpeta $1, \mathrm{n}^{\circ} 40$ ).

51 AGS, RGS, IV-1507. Se trata de las provisiones dirigidas a don Fernando Marín, abad de Santa María de Nájera, a petición del concejo de Torrecilla de Cameros, que había denunciado que este había tratado de obligar a sus vecinos a que le proporcionasen peones armados para que marchasen a combatir junto a las tropas que el duque tenía intención de enviar a Navarra para apoyar la causa de los beamonteses. También les había amenazado con quitarles los alcaldes ordinarios poniendo en su lugar un corregidor "de la mano del duque de Nájera". 
benedictinos y cistercienses de Castilla. Por ello, desde la corte se decidió el envío de un juez pesquisidor a Santa María de Nájera, el alguacil Juan de Lago, para que, al frente de una fuerza armada, restableciese en su posición a los monjes observantes que habían sido expulsados del monasterio por Fernando Marín. Alarmado, este último decidió huir del monasterio, con la intención de proseguir la defensa de su causa en la curia romana. El duque de Nájera, aunque a regañadientes, se vio forzado a prestar su colaboración para que el alguacil Juan de Lago tomase bajo su control el monasterio. Tuvo que consentir que fuesen expulsados del recinto monástico los elementos más hostiles a la observancia, encabezados por el canónigo calagurritano, licenciado de La Canal. Pero por la vía diplomática continuó en su defensa de los monjes claustrales, exigiendo que se cumpliesen los términos de la capitulación que se había firmado con don Pablo de Uruñuela. Y se dedicó sistemáticamente a torpedear la actuación del alguacil Juan Lago, contra el que reiteradamente presentó denuncias en la corte, quejándose de que era muy contrario a su persona.

De hecho, las actuaciones del alguacil Juan de Lago no bastaron para restablecer el orden y la monarquía tuvo que ordenar finalmente el envío de otro comisionado, el licenciado Galindo, a quien en 9 de marzo de 1510 se dirigió provisión ordenándole que se trasladase a Nájera para asegurar la implantación definitiva de la observancia en el monasterio ${ }^{52}$. Encontrándose este comisionado en el monasterio najerense, recibió instrucciones para que acudiese a San Millán en auxilio de los observantes, junto con el alguacil Alonso de Salinas, como ya hemos visto. Pero, una vez cumplida su misión, dejó a este último al cargo del monasterio emilianense, para regresar al de Nájera, donde los documentos del año 1511 lo siguen identificando como su gobernador ${ }^{53}$. Es decir, que, en los dos grandes monasterios riojanos de la Orden de San Benito, Fernando el Católico en el transcurso de su segunda regencia colocó dos administradores laicos para que durante un período de varios meses se hiciesen cargo de su gobierno, haciendo así posible la implantación, en ambas comunidades monásticas, de la reforma observante. Solo con tan drásticas medidas de fuerza se pudo poner fin al período de violencias en los edificios monásticos que se había iniciado con la muerte del abad de San Millán, Pedro del Castillo, en 1500, y se había acelerado tras el deceso de la Reina Católica.

\subsection{Sucesos violentos en el señorío del monasterio de San Prudencio: Disputas por el control de la granja de La Noguera}

Respecto al monasterio cisterciense de San Prudencio de Monte Laturce, sabemos que, gracias a la intervención del reformador de la Orden del Císter fray Pacífico de Liaño, se llegó a un acuerdo en los últimos años del reinado de Isabel la Católica para la introducción en él de la reforma observante. En concreto, fray Pacífico firmó un acuerdo con fray Martín de Moreda, que ocupaba en aquellos momentos la abadía, por virtud del cual este renunció a todos sus derechos sobre la misma a cambio de que se le reconociese el derecho a percibir a título vitalicio las rentas de la granja de San Bartolomé de la Noguera, perteneciente al monasterio, la cual colindaba con los

\footnotetext{
52 Publica la carta de comisión Pacheco y de Leyva, La política española, doc. $\mathrm{n}^{\circ} 23$.

53 Es el caso, por ejemplo, de una escritura de arrendamiento de frutos del monasterio que el licenciado Galindo, como tal gobernador, otorgó en 4 de agosto de 1511, de la cual existe copia, del siglo XVIII, en AHN, Estado, $3177, n^{\circ} 8$.
} 
términos de la villa señorial de Arnedo $^{54}$. En dicha concordia se había incluido una cláusula que disponía que, en caso de que fray Martín de Moreda no cumpliese con lo acordado, los monjes observantes que se iban a hacer con el control del monasterio quedaban facultados para recuperar el control de la granja. Y, efectivamente, el abad dimisionario incumplió lo acordado, porque, al parecer, nada más morir la reina Isabel la Católica, inició gestiones en la corte romana para que se le volviese a reconocer como abad perpetuo, iniciando de este modo un prolongado litigio por el control, no solo de la referida granja, sino también del propio monasterio, que se disputaron monjes claustrales y observantes. En 1505, los monjes observantes denunciaron que varios monjes claustrales, que no habían consentido la introducción de la reforma en el monasterio, huyeron del mismo y andaban "vagando sin hábitos por los montes, en menosprecio de la Orden, y haciendo escándalo en la frontera", al tiempo que les amenazaban a ellos con que les expulsarían del monasterio ${ }^{55}$. Y tiempo después se produjo la toma violenta de la granja de San Bartolomé de la Noguera, con todo su término, por varios vecinos de Arnedo, que contaron con la aquiescencia y apoyo del señor de la villa, el conde de Nieva, y de su principal representante en ella, el alcaide Pedro Díaz de Fuenmayor. Quienes ocupaban la granja en nombre de los observantes, que se habían hecho con su control por haber incumplido fray Martín de Moreda lo acordado en la concordia, fueron expulsados por la fuerza. Y la granja quedó en poder de Juan de Fuenmayor, caballero que, como ya hemos indicado en más de una ocasión, estaba casado con una sobrina del propio fray Martín de Moreda ${ }^{56}$. Este apoyo que miembros influyentes de la nobleza de la región prestaron al abad y monjes claustrales contribuyó mucho, sin duda, a enconar el enfrentamiento que estos mantuvieron con los observantes, y a propiciar que se produjesen episodios de violencia, como el descrito. La inestabilidad se prolongó durante mucho tiempo, en parte como consecuencia de la dilación del proceso que se siguió en los tribunales de la monarquía entre fray Martín de Moreda y los observantes, agravada por problemas procesales, sobre cuál era el tribunal competente para conocer de la causa $^{57}$. Así, en 1510, el reformador de la Orden de San Bernardo denunció que algunos monjes del monasterio de San Prudencio andaban "vagando e impidiendo la observancia", y no podían ser castigados como consecuencia del favor y apoyo que se les prestaba por algunos que, aunque no son identificados, es probable que fuesen caballeros del entorno, muy probablemente del círculo del conde de Nieva o del conde de Aguilar ${ }^{58}$. Como principal responsable de esta situación se señala a fray Martín de Moreda, quien seguía empeñado en hacerse con el control del monasterio, sus bienes y rentas, como abad perpetuo. Por este motivo, se habían dejado de celebrar los divinos oficios por las almas de los que lo fundaron. Y esta circunstancia movió a la monarquía en julio de 1510 a comisionar de nuevo al corregidor de Logroño, para que solucionase el problema, y asegurase que la comunidad monástica retomaba el

54 No hemos localizado el texto original de esta concordia de fray Pacífico de Liaño con fray Martín de Moreda. Se alude a su contenido en una comisión al corregidor de Logroño, en AGS, RGS, V-1508.

55 AGS, RGS, V-1505, fol. 37; AGS, RGS XII-1505, fol. 308.

56 Referencias a estos sucesos en AGS, RGS, V-1508 y AGS, Cámara-Pueblos, leg. 17, San Prudencio.

57 Después de que el corregidor de Logroño dictase una primera sentencia, fray Martín de Moreda apeló ante la Chancillería de Valladolid. Pero por cédula, el rey ordenó que conociese de la causa el Consejo Real, por tratarse de materia tocante a la reforma del monasterio y en todas las causas sobre la reforma monástica era competente el dicho Consejo, en AGS, Cámara-Cédulas, 7, 65, 2 (1509, octubre 27. Valladolid).

58 Provisión a las justicias para que proporcionen el auxilio del brazo real al reformador de la Orden de San Bernardo, AGS, RGS, VII-1510. 
desempeño de sus obligaciones espirituales ${ }^{59}$. Pero esto no fue suficiente y finalmente, para hacer frente a la amenaza planteada por las pretensiones de fray Martín de Moreda, se optó por poner en práctica una medida idéntica a la que por las mismas fechas se aplicó en los monasterios benedictinos de San Millán de la Cogolla y Santa María de Nájera, la de colocar el edificio monástico y su patrimonio bajo el gobierno directo de un administrador laico. El designado en esta ocasión por la monarquía fue un escribano vecino de Logroño, Martín López de Salvatierra, a quien los documentos del año 1511 identifican como administrador del monasterio de San Prudencio. De sus actuaciones volveremos a hablar más adelante ${ }^{60}$.

La introducción de la reforma observante en vida de la Reina Católica en este monasterio cisterciense había obligado a hacer algunas otras cesiones, que también a corto y medio plazo provocaron tensiones e inestabilidad, y mermaron la capacidad de control de la comunidad monástica sobre su patrimonio. Así, de igual modo que se cedieron las rentas de la granja de San Bartolomé de la Noguera a fray Martín de Moreda a cambio de que renunciase a la abadía, se hizo otra importante concesión a otro de los monjes claustrales más reacios a aceptar la reforma. Se trata de fray Sancho de Logroño, a quien, al iniciarse el proceso reformador hacia 1504, se le hizo entrega de un priorato dependiente del monasterio, llamado San Felices de la Sierra, ubicado cerca de Hornillos, lugar de señorío de la abadesa de Herce. La cesión se le debió efectuar para que lo usufructuase a título vitalicio. Y así lo hizo, resistiéndose incluso a ser visitado por las nuevas autoridades observantes del monasterio. Contó para ello con el apoyo de la propia abadesa de Santa María de Herce, como señora de Hornillos, quien nunca consintió que los renteros acudiesen con las rentas del priorazgo al monasterio de San Prudencio. Este monje murió en 1519 y, acto seguido, el abad de San Prudencio procedió a nombrar nuevo prior para San Felices de la Sierra. Pero chocó entonces con la abadesa de Herce, el alcalde de Hornillos y otros vecinos de este lugar, que osaron expulsar por la fuerza al nuevo prior. Como consecuencia, la comunidad monástica de San Prudencio tuvo que solicitar a la monarquía el envío de un juez pesquisidor que impartiese justicia y le proporcionase el auxilio del brazo real $^{61}$. En suma, por tanto, más de quince años después de haberse puesto en marcha la implantación de la reforma observante en San Prudencio, seguían arrastrastrándose sus consecuencias desestabilizadoras, sin haberse podido poner fin a los episodios de violencia alentados por quienes se oponían a la misma, tanto monjes como laicos vinculados a ellos por lazos de parentesco o de afinidad política.

\section{Injerencias de la alta nobleza en los monasterios y sus señoríos}

La inestabilidad vivida por los monasterios de la Rioja en el período de tránsito entre los siglos XV y XVI no estuvo exclusivamente motivada por factores internos, derivados de luchas entre personas y facciones de las comunidades monásticas por su gobierno, la administración de sus patrimonios y la definición del modelo de vida que habían de seguir sus miembros. Una parte importante de la responsabilidad de las inestables situaciones que se vivieron en este período corresponde a los linajes de

\footnotetext{
Comisión al corregidor de Logroño, AGS, RGS, VII-1510.

Varios documentos de interés al respecto en AGS, Cámara-Pueblos, leg. 17, San Prudencio.

AGS, RGS, X-1519.
} 
alta nobleza con mayor proyección política en la región, que dieron continuidad entonces a una larga tradición de intervencionismo en los monasterios y sus señoríos ${ }^{62}$.

\subsection{Los Arellano en Santa María de Herce}

El monasterio de Santa María de Herce atravesó durante la primera mitad del siglo XVI una fase de fuerte inestabilidad, en gran medida causada por las reiteradas injerencias de miembros de la alta nobleza en los asuntos internos de la comunidad monástica y en la vida política de sus lugares de señorío. En la mayor parte de las ocasiones, los protagonistas de estas injerencias fueron miembros del linaje de los Arellano, que en su calidad de señores de Cameros pretendieron dar continuidad a la actividad que, como patronos del monasterio, habían desplegado sus antecesores en dicho señorío, del linaje de los Haro, al que pertenecía el fundador del mismo, Alfonso López de $\operatorname{Haro}^{63}$.

Buena prueba de la influencia que en este período ejerció dicho linaje la tenemos en el hecho de que durante muchos años estuvo al frente de la comunidad monástica como abadesa una mujer perteneciente al mismo. En primer lugar, fue Leonor de Arellano, hija del señor de Cameros Juan Ramírez de Arellano, y, por lo tanto, hermana del primer conde de Aguilar, que profesó como monja en el monasterio en 1466 y pasó a gobernarlo como abadesa a partir de 1374. A su muerte en 1501, le sucedió en el cargo una sobrina suya que era seglar, llamada Juana de Arellano, hija de otro hermano del conde, Carlos de Arellano, señor de Ausejo, Murillo y Alcanadre, la cual en el plazo de una semana tomó el hábito y el velo, para a continuación poder ejercer como abadesa ${ }^{64}$. Durante este prolongado período en que se sucedieron al frente de la comunidad dos mujeres del linaje Arellano, los representantes varones del mismo se inmiscuyeron con frecuencia en la vida monástica. Del conde de Aguilar, hermano de la abadesa Leonor, se dijo que llegó a hacerse construir unas casas en la villa de Herce y otras junto al monasterio, y trató a los vasallos de este como si fuesen suyos propios "y en todo mandaba como señor"65.

La enorme influencia ejercida por el primer conde de Aguilar en los asuntos políticos de la villa de Herce, siendo abadesa del monasterio su hermana Leonor, queda demostrada por sucesos como el que nos ilustra una provisión dirigida al capitán de la frontera, Juan de Ribera, en febrero de $1493^{66}$. Según este documento, un individuo llamado Rodrigo de Enciso, criado del bachiller de Leza, había asesinado a un vecino de Leza, llamado Juan de Briones. El asesino, para escapar a la acción de la justicia de la villa de Leza, había huido y se había refugiado en Herce. Los oficiales de Leza requirieron a los de Herce que se lo remitiesen. Pero la remisión fue impedida por el propio conde de Aguilar y la abadesa del monasterio de Santa María como señora de la villa. A raíz de ello, el Consejo Real dirigió una provisión al conde, la abadesa y el concejo de Herce, conminándoles a que entregasen al reo en plazo de

\footnotetext{
62 Diago Hernando, "El intervencionismo nobiliario".

63 Pérez Carazo, Santa María de Herce, pp. 390-402, y Diago Hernando, "Un monasterio cisterciense". Otra rama de este mismo linaje Haro, la de los señores de Vizcaya, tuvo un activo papel en la fundación del otro monasterio cisterciense femenino de la región, el de Santa María de Cañas. Véase al respecto Baury, Les religieuses.

64 Noticia en Biblioteca de la Real Academia de la Historia, Colección Salazar y Castro, D-9, fol. 126r.

65 Según la epístola de relación que envió a mediados del XVI Juana Bélaz de Navarra al abad de Iranzu, que cita Pérez Carazo, Santa María de Herce, p. 395.

66 Comisión a Juan de Ribera, AGS, RGS, II-1493, fol. 185.
} 
seis días. Fueron requeridos con la provisión pero no la quisieron cumplir. En consecuencia, tuvo que intervenir el capitán de la frontera, con sede en Logroño, que envió a su hijo Juan de Silva a Herce para que se apoderase del preso. Pero no pudo hacerlo, porque el conde, la abadesa, el concejo y su alcalde, le facilitaron a este último refugiarse en el interior del edificio monástico, desde donde huyó a paradero desconocido. Por ello, los parientes del asesinado Juan de Briones reclamaron que se castigase al conde de Aguilar, la abadesa y concejo de Herce, y que se les indemnizase a ellos con 50.000 mrs. Desconocemos el desenlace final del litigio, pero lo que nos importa resaltar es que en este episodio el conde de Aguilar se comportó como auténtico detentador del poder efectivo en la villa de Herce.

Después, durante el período en que gobernó como abadesa Juana de Arellano, la participación de los varones del linaje Arellano en los asuntos internos de Herce continuó siendo muy intensa, aunque no siempre sus actuaciones se basaron en una relación de colaboración con su parienta la abadesa. Por el contrario, se produjeron episodios de graves enfrentamientos. El principal tuvo lugar en 1506, cuando el conde de Aguilar, Carlos de Arellano, primo de la abadesa, entró de forma violenta en la villa de Herce, acompañado del señor de Ausejo, Juan de Arellano, hermano de esta última. Ambos trajeron consigo un nutrido grupo de hombres armados para hacerse con el control por la fuerza de la villa. Se apoderaron incluso de la posada en la que residía Alonso de Arellano, a quien trataron de matar ${ }^{67}$. La reacción de la abadesa y las monjas fue de fuerte hostilidad y, en defensa de sus intereses, acudieron a denunciar a la corte romana, donde lograron que al año siguiente, en 1507, el papa Julio II pronunciase sentencia de excomunión contra el conde de Aguilar ${ }^{68}$. Por otra parte, para impedir que este continuase reforzando su posición en la villa, lograron que la monarquía expidiese provisiones prohibiendo que le fuesen vendidas casas o heredades en el término de Herce, pues, a juicio de la abadesa y monjas, con dichas compras no perseguía otro objetivo que "enseñorearse" de la villa"

La presión ejercida por los condes de Aguilar, no obstante, prosiguió en los años siguientes con renovada intensidad. Así lo testimonian varias denuncias presentadas en el año 1512, que evidencian la existencia de un enconado enfrentamiento banderizo en el seno de la sociedad política local de esta villa, que en gran medida era consecuencia de las injerencias en los asuntos locales del conde de Aguilar y otros miembros del linaje Arellano. Así, en concreto, Diego de Urlenes, merino por la abadesa, presentó una denuncia ese año contra Miguel de Vidaurreta, alcaide de Arnedillo y vecino de Herce, de quien dijo que vivía con el conde de Aguilar. Por ello, pese a que el rey había prohibido al conde que continuase ejerciendo la encomienda sobre esta villa de señorío monástico ${ }^{70}$, este individuo "tuvo formas con muchos parientes para que el conde fuese a la villa de Herce y muchos vecinos le jurasen por encomendero". Según el denunciante, de esta actuación "se siguieron muchos daños a muchos vecinos de Herce", en especial, a algunos criados y servidores de la abadesa que no quisieron adherirse a dicha parcialidad, los cuales se vieron forzados a huir de sus casas y por ello perdieron más de 20.000 mrs. El merino también acusó a Miguel de

\footnotetext{
Provisión al conde de Aguilar, AGS, RGS, I-1507.

Diago Hernando, "Un monasterio cisterciense", p. 140.

Provisión al concejo de Herce, AGS, RGS, XI-1506, y AHN, Clero, libro 5760, doc. 547.

70 En la provisión que la monarquía dirigió al conde de Aguilar a principios del año 1507, tras su entrada violenta en Herce, ya se hacía constar que se le había prohibido con anterioridad ejercer la encomienda sobre el monasterio (AGS, RGS, I-1507).
} 
Vidaurreta de haberse dedicado a conceder préstamos con usura, por los que había sido denunciado ante la Chancillería, de haber propiciado que se diese una paliza a un vecino llamado maestre Francisco, que le puso en peligro de muerte, y de haber salido una noche con personas armadas a matar a Juan López, quien resultó herido. Y pese a la gravedad de todos estos delitos, concluía en su denuncia el merino, no había recibido ningún castigo porque le protegía el conde de Aguilar, que era su patrón ${ }^{71}$.

En esta misma línea, también se inscribe la denuncia presentada por Constanza de la Bastida, viuda de Pedro de Quirós, alguacil de Herce, contra Francisco de Vidaurreta, hermano de Miguel. Se quejó en concreto de que los oficiales de la justicia de esta villa habían procedido a ejecutar en bienes de este individuo, tomándole 35 fanegas de trigo. Pero acto seguido el conde de Aguilar había acudido en persona al lugar y, por fuerza y contra voluntad de su difunto marido, había tomado el trigo y lo había devuelto a Francisco de Vidaurreta, porque era su criado ${ }^{72}$.

Un punto de vista diamentralmente opuesto al del merino manifestaron, sin embargo, los propios hermanos Vidaurreta, que no se contentaron con negar las acusaciones, sino que presentaron denuncia contra la propia abadesa, sus oficiales y ciertos vecinos de la villa que militaban en su "parcialidad". En concreto, Francisco de Vidaurreta denunció que unos vecinos de Herce, a los que no identifica, le habían derribado un palomar y un cercado ${ }^{73}$. Y, junto con su hermano Miguel, acusó a la abadesa de haberles tomado sus casas y bienes, a raíz de la cual había intervenido en el asunto, a petición suya, el corregidor de Logroño, que había dictado sentencia a su favor, la cual, sin embargo, no se había llevado a ejecución por los oficiales de la justicia de Herce ${ }^{74}$. En la misma línea, los dos hermanos denunciaron que Fadrique de Arellano y otros vecinos de Herce les debían dinero que no podían cobrar como consecuencia del favor que dicho caballero disfrutaba en la villa, por ser esta de señorío de su parienta la abadesa, la cual además les profesaba a ellos manifiesta enemistad ${ }^{75}$.

Todo apunta, pues, a que en aquellos momentos la sociedad política de Herce se encontraba escindida en dos facciones irreconciliables, una encabezada por la abadesa, apoyada por algunos miembros del linaje Arellano, como Fadrique, y la otra por el propio conde de Aguilar, que había integrado en su clientela a varios influyentes vecinos de la villa, en particular de la familia Vidaurreta. No obstante, cabe presumir que estas facciones estuviesen sometidas a fluctuaciones en su composición, que el carácter fragmentario de la documentación conservada no permite detectar en detalle.

Por lo demás, las relaciones de la abadesa Juana con los miembros de la rama del linaje Arellano a la que ella misma pertenecía, la de los señores de Murillo y Ausejo, también estuvieron marcadas en ciertos momentos por la hostilidad. En primer lugar, su propio hermano Juan acompañó en 1506 al conde de Aguilar en su entrada violenta en Herce. Pero, además, con posterioridad otro importante factor se sumó para enturbiarlas aún más. Se trata de la pretensión, por parte de la abadesa, de que se le hiciese partícipe de la herencia de sus padres, Carlos de Arellano y María de Navarra, que, según ella, le había sido usurpada por su hermano Juan, señor de Ausejo. Con este motivo, presentó una demanda en la Chancillería de Valladolid en el año 1537 , si bien la tramitación del contencioso se demoró durante muchos años, de

\footnotetext{
Comisión al corregidor de Logroño, AGS, RGS, V-1512.

Comisión al corregidor de Calahorra, AGS, RGS, XII-1512.

Comisión al corregidor de Calahorra, AGS, RGS, V-1512.

Comisión al corregidor de Calahorra, AGS, RGS, V-1512.

AGS, RGS, V-1512.
} 
manera que la primera sentencia de vista no fue pronunciada por los jueces hasta el año 1553, cuando ya hacía varios años que había fallecido la propia Juana. El monasterio cisterciense de Santa María, como su legítimo heredero, pudo beneficiarse entonces, sin embargo, de la decisión judicial que obligó a los descendientes de Juan de Arellano a que hiciesen entrega a la comunidad monástica de la tercera parte de los bienes dejados a su muerte por el señor de Ausejo, Carlos de Arellano, y su mujer María de Navarra, que había correspondido por herencia a dicha abadesa, como una de los tres descendientes legítimos de dicho matrimonio, junto a sus hermanos Juan, señor de Ausejo, y Carlos. Esta sentencia fue confirmada en revista en febrero de 1554 y de ella se sacó ejecutoria en marzo de ese mismo año ${ }^{76}$. Pero los litigios continuaron, por dificultades que se plantearon en la ejecución de la misma, que afectaron en particular al término de Sartaguda, enclave navarro en la frontera con Castilla con importantes aprovechamientos de pasto, que constituía una parte fundamental de la disputada herencia ${ }^{77}$.

\subsection{Injerencias de los condes de Nieva en el monasterio de Herce}

Pese a que fue el linaje de los Arellano, condes de Aguilar, como sucesores en el señorío de Cameros de los López de Haro, fundadores del monasterio, el que más presión ejerció sobre la comunidad cisterciense de Santa María de Herce en los siglos XV y XVI, otros linajes de alta nobleza con fuerte implantación en el escenario riojano también mostraron evidente interés por inmiscuirse en sus negocios. Cabe destacar, desde esta perspectiva, el caso de los condes de Nieva, señores de la villa de Arnedo, muy próxima a Herce. En los primeros años del siglo XVI, el titular de este condado, en quien confluía la sangre de los Velasco y de los Zúñiga, militaba en el mismo bando que el conde de Aguilar, enfrentado al bando liderado por el duque de Nájera, del linaje Manrique. Estos dos bandos mantuvieron una relación de enconada hostilidad que desestabilizó el escenario político riojano en las últimas décadas del siglo XV y las primeras décadas del XVI, y que tuvo consecuencias incluso para el reino de Navarra, que atrajo las intervenciones directas de estos tres nobles, que llegaron incluso a enviar allí tropas para participar en acciones militares ${ }^{78}$. La buena sintonía existente entre el conde de Aguilar y el conde de Nieva, fruto entre otros factores de su compartida hostilidad hacia los Manrique, es la que explica la circunstancia singular de que en el año 1506 ambos acudiesen a la villa de Herce con la intención de dedicar una jornada de esparcimiento a la caza en el monte. Enterado de sus intenciones, sin embargo, el alcaide de la fortaleza de Ocón envió a requerirles que no osasen penetrar en el término de esta villa, porque el duque de Nájera, su señor, lo tenía vedado y no admitía que se cazase en él. A este requerimiento el conde de Aguilar respondió, sin embargo, que, por ser montero mayor del rey, podía entrar libremente donde quisiere "a monte". La tensión se respiraba en el ambiente y estalló al día siguiente con motivo de que los dos condes salieron a correr ciertos puercos que tenían concertados en los términos de Arnedo. Pese a que se trataba de una jornada de esparcimiento dedicada al noble deporte de la caza, los dos nobles llevaron consigo algunos peones armados "para la bocería", porque el monte era grande. Y

\footnotetext{
AChV, RE, 802-25 (1554, marzo 02. Valladolid).

AChV, RE, 861-28 (1556, junio 13) y AChV, RE, 952-9 (1559, agosto 14).

Diago Hernando, "El poder de la nobleza" e Idem, "Las comarcas castellanas".
} 
ocurrió que, en un determinado momento, los puercos se metieron en los términos de Ocón, por lo que algunos monteros con perros y otra gente entraron también en dichos términos en su persecución. El alcaide de Ocón reaccionó ante esta violación de su espacio jurisdiccional poniéndose al frente de un grupo numeroso de peones armados y algunos a caballo, que se dirigió contra los intrusos. En la refriega que entonces se produjo algunos ballesteros lanzaron tiros con los que hirieron a un perro y mataron a otro. No parece que como consecuencia del incidente resultase herida ninguna persona, pero a pesar de ello la monarquía lo consideró como una grave violación del orden público y comisionó al capitán de la frontera, Juan de Ribera, para que hiciese pesquisa y castigase a los culpables ${ }^{79}$. Fue una más de las numerosas manifestaciones del conflicto banderizo entre los principales linajes de la alta nobleza que asolaba la región riojana, pero hemos querido detenernos en su análisis porque pone de manifiesto hasta qué punto la vida cotidiana de Herce, pese a su condición de villa de señorío monástico, se veía afectada por la presencia nobiliaria, en esta ocasión conjunta, de los condes de Nieva y Aguilar.

Pero la presión de los condes de Nieva sobre el monasterio y villa de Herce no se limitó a incidentes ocasionales en que interviniesen como simple colaboradores del linaje Arellano. Al parecer, buscaron satisfacer, por su propia cuenta, más altas ambiciones. Lo sugiere en concreto una carta que la abadesa de Herce, Juana Vélez de Medrano, dirigió a mediados del siglo XVI a su superior, el abad de Iranzu, en la que afirmaba literalmente lo siguiente:

Sepa vuesa merced que nuestra casa está en los confines de los condados de Nieba e Aguilar, e como el Conde de Nieba quisiera que nos amparásemos dél, e no lo hemos hecho en sus cosas como él quisiera, haze como los otros contra la casa, y estamos determinadas de no dar entrada a los unos ni a los otros, porque ya que no fuimos dichosas que nuestros fundadores se perpetuasen para ser dellos amparadas, entendemos que a todos los otros seremos ovejas agenas e al fin profanadas dellos y tiranizadas ${ }^{80}$.

La principal villa de la Rioja Baja sobre la que los condes de Nieva ejercían el señorío jurisdiccional era la de Arnedo, y desde la misma se lanzaron varios ataques a la comunidad cisterciense de Herce durante el reinado de los Reyes Católicos. El episodio más grave tuvo lugar en 1494 cuando la abadesa y monjas denunciaron ante el Consejo Real a un vecino de dicha villa llamado Juan de Berrañón, acusándole de estar edificando cerca de Herce una fortaleza, en flagrante violación de las leyes que prohibían la construcción de tales edificios sin licencia del rey ${ }^{81}$. Además, le acusaron de haber tomado por la fuerza bienes y rentas del monasterio y de algunos de sus vasallos, sin que se hubiese podido actuar contra él por vía de justicia, debido a que se le dispensaba trato de favor en la villa de Arnedo, de donde era vecino, por los oficiales nombrados por su señor el conde de Nieva ${ }^{82}$.

79 Comisión a Juan de Ribera, AGS, RGS, III-1506, fol. 169.

80 Pérez Carazo, Santa María de Herce, pp. 400-401.

81 Comisión al licenciado Francisco de Vargas, corregidor de Calahorra y Logroño, para que averigüe si Juan de Berrañón edifica la dicha fortaleza, y haga que cese la obra si no dispone de licencia, AGS, RGS, VII-1494, fol. 186.

82 Comisión al licenciado Francisco de Vargas, AGS, RGS, VII-1494, fol. 185. 
La presión ejercida por los condes de Nieva sobre el monasterio de Herce, por otra parte, lejos de amortiguarse, fue por el contrario en ascenso conforme avanzó el siglo XVI, hasta el punto de que sus actuaciones llegaron a desestabilizar la vida conventual, llevándoles incluso a entrar en conflicto con sus antiguos aliados, los condes de Aguilar. Desde esta perspectiva merece la atención detenerse en el análisis de los acontecimientos que se produjeron tras la muerte de la ya aludida abadesa Juana de Arellano, a comienzos de la década de 1540. Entonces dos mujeres se disputaron la silla abacial, una perteneciente al mismo linaje de la difunta, llamada Leonor de Arellano, que era hermana del conde de Aguilar, y la otra, doña Juana Vélez de Navarra, emparentada con otros destacados nobles castellanos y navarros, pues era sobrina del conde de Nieva y del mariscal, marqués de Torres. Sabemos que la disputa se resolvió finalmente por la jurisdicción eclesiástica al sentenciar el tribunal de la Rota en 1542 a favor de Juana Vélez de Navarra, reconociéndole facultad para despojar a su rival Leonor de Arellano por intrusa ${ }^{83}$. Pero previamente se habían producido "alborotos y ruidos de gentes", porque se habían movilizado con sus clientelas armadas los parientes nobles de cada una de las dos candidatas a fin de favorecer la causa de la suya. Para poner fin a estos desórdenes la monarquía comisionó al alcalde Montalbo, quien con propósito pacificador decretó el destierro de la villa de Herce de los condes de Aguilar y Nieva, de los marqueses de Torres y Falces, y de otros muchos individuos no identificados. Más adelante, otro comisionado regio, el licenciado Villagómez, alcalde de la Chancillería, ordenó a su vez el destierro perpetuo de esta misma villa del licenciado Garcés, por haber intervenido en estos desórdenes, a favor de la parte de doña Juana Vélez y del mariscal ${ }^{84}$.

Era este letrado un vecino de la villa soriana de Ágreda, que había entrado a formar parte de la clientela del conde de Nieva, quien le nombró gobernador de sus señoríos riojanos, que tenían su capital en Arnedo. Su vinculación con el monasterio no se derivaba solo de esta circunstancia, sino que también tenía intereses familiares en el mismo, pues habían profesado en él como monjas dos de sus hijas. Por esta última razón, quizás su insistencia en inmiscuirse en los asuntos internos de esta comunidad cisterciense superó a la de su propio patrón, el conde de Nieva, pues mientras que no se tiene noticia de que este último, una vez instalada en la silla abacial su candidata, Juana Vélez de Medrano, volviese a hacer acto de presencia en Herce, de donde fue desterrado, el licenciado Garcés dejó muy pronto de acatar la pena de destierro que a él también le fue impuesta por otro juez pesquisidor. Lo denunciaron a fines del año 1552 ante la Chancillería de Valladolid dos monjas de esta comunidad cisterciense, Ángela y María de Arellano, secundadas por el procurador fiscal, el licenciado Alderete. Le acusaron, en efecto, de que desde hacía tiempo venía quebrantando el destierro, por acudir con frecuencia a la villa de Herce, llegando incluso a penetrar en el edificio monástico para permanecer en su interior varios días seguidos. Solicitaron, en consecuencia, que, en castigo por este grave delito de desacato a la justicia real, fuese llevado preso a la cárcel de Corte. El denunciado no negó los hechos, reconociendo en efecto que, pese a la pena de destierro perpetuo contra él decretada, había frecuentado la villa de Herce y el propio monasterio. Pero en su descargo argumentó que en todo momento había procedido muy "recatadamente" y había estado "públicamente" en la "hospedería y recogimiento de huéspedes del monasterio". Añadió

\footnotetext{
$83 \quad$ AHN, Clero, leg. 2862, doc. $n^{\circ} 81$.

84 Información contenida en AChV, RE, 824-67 (1555, febrero).
} 
que siempre había acudido para negocios del monasterio, por ser la abadesa y algunas monjas sus "deudas y parientas", y tener en él dos hijas. Y, para quitar gravedad al delito de desacato por su inobservancia de la pena de destierro, insistió en que los desórdenes por los que se le había desterrado, asociados a la disputa por la elección de abadesa, hacía muchos años que se habían producido, mientras que de sus estancias recientes en el monasterio no se había derivado ningún escándalo. Todos estos argumentos no lograron, sin embargo, convencer a los jueces de la Chancillería, que en mayo de 1554 pronunciaron sentencia condenándole a destierro del reino por cinco años, y a que cumpliese la pena de destierro perpetuo de la villa de Herce y su monasterio, en que ya había sido condenado con anterioridad ${ }^{85}$.

El hecho de que fuesen dos monjas de apellido Arellano las que presentaron la denuncia contra el licenciado Garcés por el incumplimiento de la pena de destierro proporciona un claro indicio de que en la comunidad cisterciense todavía no habían cicatrizado las heridas producidas por la disputa por la silla abacial desencadenada tras la muerte de Leonor de Arellano, que había llevado a que chocasen el conde de Aguilar y el conde de Nieva, antiguos aliados, pero que ahora defendían a diferentes candidatas a abadesa. Las actuaciones del licenciado Garcés nos proporcionan, por otra parte, una buena prueba de la persistencia de las injerencias de los laicos en la vida cotidiana de las comunidades monásticas hasta fechas bien avanzadas del siglo XVI, pese a los esfuerzos que se hicieron para aislar a dichas comunidades de los contactos perturbadores con el mundo exterior mediante la implantación generalizada del régimen de la observancia.

\subsection{Presión nobiliaria sobre el monasterio de Santa María de Cañas}

También muy afectado por la presión nobiliaria se vio en las primeras décadas del siglo XVI el otro monasterio cisterciense femenino ubicado en la Rioja, Santa María de Cañas. A lo largo del siglo XV había estado sufriendo un proceso de progresivo debilitamiento, que se tradujo en operaciones de enajenación de importantes elementos de su patrimonio en favor de nobles o concejos de la comarca. Así, en 1443, con la autorización de la abadesa de las Huelgas de Burgos, vendió al mariscal Sancho de Londoño todos los derechos y propiedades que le pertenecían en el lugar de Hervias, a cambio de un juro de heredad de $4.000 \mathrm{mrs}^{86}$. Con anterioridad, en $1407 \mathrm{el} \mathrm{monas-}$ terio se había desprendido, siempre con autorización de la abadesa de Las Huelgas de Burgos, de otro elemento importante de su patrimonio, al ceder a censo perpetuo al concejo de la villa de Haro, perteneciente entonces al señorío del infante Fernando de Antequera, futuro rey de Aragón, su lugar solariego de Naharruri, hoy conocido como Casalarreina. Las razones alegadas para justificar la operación constituyen toda una confesión de debilidad, pues se apela en el documento a la circunstancia de que "los lugares comarcanos son grandes y de mayores pueblos y de grandes y

85 La ejecutoria en que se incorpora esta sentencia de vista y la de revista por la que se desestimó la apelación, en AChV, RE, 824-67 (1555, febrero).

86 Licencia para efectuar el trueque, otorgada en el monasterio de las Huelgas de Burgos (1443, agosto 09), AHN, Nobleza, Frías, c. 417, d. 29 y Privilegio de Juan II concediendo al monasterio de Cañas juro perpetuo de 4.000 mrs. (1443, diciembre 10), AHN, Nobleza, Frías, c. 420, d. 1. Por dicho privilegio, Juan II concedería al monasterio de Cañas juro perpetuo de 4.000 mrs. sobre las alcabalas de pan y vino de Cañas, Canillas, y Matute, por cesión de Sancho de Londoño, de los 10.000 que tenía. A cambio este había recibido del monasterio los solares, casas, viñas, piezas y rentas que le eran propias en Hervias. 
poderosos señores, ocupan los términos y pastos del dicho nuestro lugar por diversas personas, y oprimen a los labradores que allí viven, en tal forma que se despuebla de cada día, y se menoscaban la renta y la jurisdicción del monasterio" $" 87$.

La documentación proporciona efectivamente noticias que dan fe de las dificultades con que tropezaba el monasterio de Cañas para defender su patrimonio frente a los intentos de usurpación de vecinos poderosos. Entre ellos encontramos durante el reinado de los Reyes Católicos nombres como el de Juan de Leiva, miembro de un linaje de nobleza media con fuerte arraigo en la región riojana, que proporcionó monjas e incluso abadesas a la propia comunidad de Santa María de Cañas ${ }^{88}$. En 1489 se falló un pleito que había opuesto a este caballero con esta comunidad cisterciense por razón de ciertas heredades de pan llevar que esta poseía en los términos del lugar de Tirgo y que le habían sido ocupadas por aquel. Los reyes ordenaron entonces a sus correspondientes oficiales de la justicia en la región que amparasen y defendiesen a la abadesa y monjas en la posesión que habían tenido de las dichas heredades de pan llevar, para que pudiesen recibir sus frutos y rentas libremente, y ordenaron a Juan de Leiva que tornase a los renteros que explotaban dichas heredades en Tirgo todo el cereal que les había llevado del año 1488, dejando de inquietar en adelante al monasterio en su posesión de las heredades y rentas ${ }^{89}$.

Por aquellas mismas fechas también tenemos noticia de ciertas dificultades para mantener el control de su patrimonio en el término de la ciudad realenga de Logroño. En concreto, en 1489 la abadesa y monjas denunciaron ante la monarquía que diversas personas les tenían tomados muchos bienes y posesiones en dicha jurisdicción, $\mathrm{y}$, aunque les habían requerido que los devolviesen, no habían accedido a hacerlo. En respuesta a la demanda, los reyes comisionaron a su corregidor en esta ciudad para que conminase a los ocupantes a devolver los bienes tomados ${ }^{90}$.

La creciente debilidad del monasterio de Cañas trató de ser aprovechada por poderosos representantes de la nobleza en la región para ampliar sus bases de poder, adquiriendo algunos elementos del patrimonio señorial monástico en condiciones ventajosas. Resultan de interés desde esta perspectiva las negociaciones que esta comunidad cisterciense mantuvo con el condestable de Castilla, Bernardino Fernández de Velasco, en torno al año 1511, coincidiendo con el momento del recrudecimiento del enfrentamiento con sus vasallos de Negueruela. En efecto, por una licencia que otorgó a la abadesa y monjas de Santa María de Cañas su superior jerárquica, la abadesa del monasterio de Las Huelgas de Burgos, en este año, nos consta que el monasterio riojano se encontraba en una apurada situación financiera, agravada por los gastos que le estaba ocasionando el seguimiento del pleito con sus vasallos rebeldes de Negueruela y la necesidad de efectuar reparaciones en el edificio monástico. Para recaudar el dinero preciso para afrontar dichas necesidades, la abadesa y monjas no habían encontrado otra vía que poner a la venta algunos de los lugares de su patrimonio señorial, en concreto algunos que eran "de poca renta y provecho". Y por ello habían llegado a un acuerdo con el condestable en virtud del cual le venderían los lugares de Quintanilla y Valluércanos por cierta cantidad de dinero. Así mismo,

87 Carta de censo enfitéutico (1407, noviembre 10), AHN, Nobleza, Frías, c. 416, d. 21.

88 Sobre la identidad de las abadesas de Cañas durante el período bajomedieval proporciona información Marcos Pascual, Historia y jurisdicción.

89 Ejecutoria dirigida a las justicias de Nájera, Logroño, Santo Dominmgo de la Calzada, Bañares, Leiva y Tirgo, AGS, RGS, III-1489, fol. 316.

90 AGS, RGS, II-1489, fol. 295. 
quedaban obligadas a venderle el lugar de Negueruela en caso de que obtuviesen sentencia favorable en el pleito que estaban siguiendo contra sus vasallos, por la que se ratificase la pertenencia del lugar al señorío monástico. En tal caso, el condestable les habría de pagar a razón de 10.000 mrs. por cada vasallo, más 100.000 mrs. en dinero en metálico, más una casulla y una pitanza, más otra cantidad no precisada por el cereal de renta y juro que el monasterio poseía en el lugar. Pero, en el caso de que la venta de Negueruela se llevase a efecto, quedaría anulada la de Quintanilla y Valluércanos. Por otra parte, si el monasterio no lograse vencer en el pleito que seguía con los vecinos de Negueruela, quedaba obligado a devolver al contado al condestable los $100.000 \mathrm{mrs}$. que le prestaba para afrontar sus urgentes necesidades financieras ${ }^{91}$. Se trataba de un acuerdo bastante complejo, que contemplaba diversas alternativas, ninguna de las cuales parece que finalmente se vieron cumplidas, pues tanto Quintanilla como Valluércanos como Negueruela siguieron formando parte a lo largo del siglo XVI del señorío del monasterio de Cañas, y no se incorporaron formalmente al patrimonio de la casa de Velasco. De lo que no cabe duda es de que el condestable accedió a socorrer financieramente a la atribulada comunidad monástica, prestándole $100.000 \mathrm{mrs}$. a cambio de que se le facilitase la adquisición de algunos lugares de su señorío con los que redondear su patrimonio en la comarca riojana. Los motivos por los que finalmente ninguno de los lugares barajados fue efectivamente adquirido por la casa de Velasco no los conocemos en detalle. Pudo influir el hecho de que Bernardino murió poco después sin descendencia masculina legítima y, en sus mayorazgos, le sucedió su hermano Íñigo. En cualquier caso, la sombra de la casa de Velasco se continuó proyectando sobre algunos de los lugares contemplados en la operación del año 1511. En concreto, se ha de destacar el caso de Quintanilla de San García, lugar donde el monasterio de Cañas no ejercía el señorío con exclusividad, sino que lo compartía con el monasterio de Las Huelgas de Burgos. El interés de la casa de Velasco por este lugar ya se había venido manifestando desde hacía mucho tiempo. En concreto, cabe recordar que Pedro Fernández de Velasco lo había tenido ocupado, llamándose encomendero, hasta que Juan I le obligó a desocuparlo en $1380^{92}$. No obstante, posteriormente, los propios vecinos buscaron la protección de sus sucesores de la casa de Velasco, solicitándoles que les tomasen en su encomienda hasta bien entrado el siglo XVI, según prueba un interesante documento del año $1531^{93}$.

\section{Intensificación de los conflictos con los vasallos en los señoríos monásticos}

El período cronológico que estamos tomando en consideración en el presente trabajo fue en algunos ámbitos de Europa especialmente convulso desde el punto de vista de la evolución de las relaciones entre señores y vasallos en los territorios de señorío. En el Imperio en particular, crecientes tensiones se fueron manifestando de forma progresiva a lo largo de la segunda mitad del siglo $\mathrm{XV}^{94}$, para culminar en el

\footnotetext{
AHN, Nobleza, Frías, c. 294, d. 37 (1511, abril 04. Burgos).

Según consta por sentencia de 27 de diciembre de 1380, en AHN, Clero, carpeta 1025-23.

AHN, Nobleza, Frías, c. 364, d. 6

94 Sobre los movimientos antiseñoriales en el Imperio durante la segunda mitad del siglo XV, véase Wunderli, Peasant Fires. Para la Corona de Castilla en general interesa para este período en particular Oliva Herrer, Justicia contra señores.
} 
estallido de la célebre guerra Campesina del año 1525, que coincidió con la primera expansión del movimiento eclesiástico de la Reforma luterana ${ }^{95}$. Este proceso de fuerte carácter antiseñorial no solo se manifestó con notoria virulencia en los territorios sometidos al poder de la nobleza y los príncipes. También afectó a los señoríos de los monasterios, que tuvieron que hacer frente a actitudes de creciente hostilidad, que para muchos desembocó en su definitiva disolución, derivada de la adopción del credo reformado por los detentadores del poder en los ámbitos donde se ubicaban ${ }^{96}$.

En los monasterios riojanos de las primeras décadas del siglo XVI, las relaciones con sus vasallos no alcanzaron el grado de tensión y sangrienta hostilidad que caracterizó a las que mantuvieron por entonces muchos de sus homólogos del Imperio con los campesinos a ellos sometidos. Para explicar esta diferencia se ha de tener en cuenta que los derechos señoriales ejercidos por todos los monasterios de la Rioja eran mucho más limitados ${ }^{97}$ que los que tenían reconocidos muchos de sus homólogos en el Imperio, en cuyas tierras abundaban en ocasiones los siervos (Leibeigene), con serias limitaciones en su libertad de movimiento e incluso en su capacidad de contraer matrimonio con quien quisiesen ${ }^{98}$.

Pero, aunque no se llegó a los extremos de las tierras del Imperio, también en la Rioja proliferaron en los años finales del siglo XV y en las primeras décadas del siglo XVI los enfrentamientos entre los monasterios y sus vasallos, por motivos muy diversos. En estudios monográficos previos se ha prestado atención al análisis del enconado conflicto que enfrentó al monasterio de Santa María de Nájera con sus vasallos de Torrecilla de Cameros, la villa más poblada y dinámica desde el punto económico de su señorío, del que sostuvo San Millán de la Cogolla con sus vasallos de los concejos del Valle de San Millán, y del que enfrentó al monasterio de Valvanera con sus vasallos de la villa de Anguiano ${ }^{99}$. Para evitar reincidencias, centraremos nuestra atención en abordar otros conflictos que afectaron a otras comunidades monásticas, que han pasado más desapercibidos para la historiografía, y que confirman la impresión de que estos años de tránsito entre el Medievo y la Edad Moderna fueron inusualmente convulsos desde el punto de vista de la evolución de las relaciones entre los monasterios de la Rioja y sus respectivos vasallos.

\subsection{Conflictos antiseñoriales en el abadengo de Santa María de Herce}

Entre los monasterios que en el espacio regional riojano disfrutaban de mayores atribuciones jurisdiccionales destaca el cisterciense femenino de Santa María de Herce, pues tenía reconocido el ejercicio de la jurisdicción civil y criminal sobre la propia villa de Herce, donde se ubicaba el edificio monástico, y sobre otros núcleos menores de su entorno, como Hornillos, La Santa y Torremuña, con sus aldeas, que en

95 Para la guerra Campesina del 1525, véase Blickle, Die Revolution von 1525 y Blickle, Buszello y Endres, Der deutsche Bauernkrieg. Sobre el papel del factor religioso en estos conflictos es de interés Blickle, Reformation und kommunaler.

96 Un interesante análisis de todas estas cuestiones en el ámbito de influencia de la ciudad de Zúrich, donde triunfó la reforma, en la reciente monografía de Kamber, Reformation als bäuerliche.

97 Sobre el perfil como señores de vasallos de los monasterios riojanos, véase Diago Hernando, "Los señoríos monásticos".También interesa la información aportada por la averiguación de 1553, publicada por Alonso Martín y Palacio Sánchez-Izquierdo, Jurisdicción, gobierno y hacienda.

98 Un ejemplo paradigmático de monasterio del Imperio con amplios derechos señoriales y siervos bajo su dependencia, el cisterciense de Salem, es analizado en la clásica monografía de Rösener, Reichsabtei Salem.

99 Diago Hernando, "Los conflictos antiseñoriales". 
total reunían en torno al medio millar de vecinos ${ }^{100}$. Esta situación contrasta con la de otros monasterios de la región, incluidos los de monjes benedictinos de San Millán de la Cogolla y Santa María de Nájera, que en un número importante de sus lugares de señorío no podían ejercer facultades jurisdiccionales plenas, faltándoles en muchos casos la jurisdicción criminal, al tiempo que la jurisdicción civil con frecuencia solo la podían ejercer de forma compartida con otras instancias. Tal contraste no deja de resultar paradójico, si tenemos en cuenta que el monasterio de Herce -al tratarse de una comunidad de mujeres, que además vivían conforme a la regla del Císter, que había surgido como reacción frente a la señorial y aristocrática Orden de Cluny- podía tropezar con más dificultades que las comunidades monásticas masculinas para el ejercicio efectivo de la jurisdicción criminal, en particular, y de la labor de gobierno, en general. Para explicar esta aparente paradoja no debemos olvidar que Santa María de Herce fue fundado por un miembro de la más alta nobleza, el señor de Cameros, que para dotarlo se desprendió de unos cuantos lugares de su señorío, en los que tenía reconocidas facultades jurisdiccionales plenas.

En cualquier caso, para las abadesas y monjas de Santa María de Herce, el disponer de tan amplias atribuciones jurisdiccionales, no les facilitó la tarea del gobierno de sus vasallos. Por el contrario, tuvieron que hacer frente a reiteradas dificultades, derivadas en parte de la propia injerencia de los señores de Cameros, del linaje Arellano, en el período que nos ocupa. Un momento de particular tensión se vivió durante el reinado de Enrique IV. En 1455 la abadesa y monjas denunciaron ante este monarca que sus súbditos de la villa de Herce "en grand rebelión" se habían alzado contra ellas, y se negaban a satisfacer las rentas y prestaciones, y a cumplir sus mandamientos. Habían incluso designado un oficial de la justicia que de facto obedecía al señor de Cameros, Juan Ramírez de Arellano. El rey ordenó entonces a los vecinos que se sometiesen a la autoridad de su legítima señora la abadesa, pero estos replicaron que no era cierto que ellos se hubieran entregado en encomienda a este poderoso noble. Hay indicios, no obstante, de que se había establecido una relación de alianza y cooperación entre el concejo de Herce y el señor de Cameros. Por ello, el conflicto continuó recrudeciéndose en los meses siguientes y para su resolución hubo que recurrir a unos jueces árbitros, que pronunciaron sentencia arbitral en 1457. En ella se reconoció a la abadesa el derecho a nombrar como oficial de la justicia a quien quisiese, siempre que fuese de los labradores residentes en la villa y se procediese a su renovación cada cierto tiempo. También se le reconoció el derecho a continuar exigiendo a sus vasallos las mismas prestaciones que hasta entonces ${ }^{101}$.

A comienzos del siglo XVI las tensiones entre el monasterio y algunos de sus vasallos de Herce volvieron a resurgir con fuerza, mezclándose con episodios de injerencia de caballeros del linaje Arellano en la vida política local. Así, en el inestable período que siguió a la muerte de Isabel la Católica, la abadesa, contando con el apoyo de su hermano, Alfonso de Arellano, y de otro miembro de este mismo linaje, Fadrique, hermano del conde de Aguilar, sostuvieron un enconado conflicto con un

100 Detalles sobre los derechos jurisdiccionales que ejercía el monasterio en Herce, según la averiguación de 1553, en Alonso Martín y Palacio Sánchez-Izquierdo, Jurisdicción, gobierno y hacienda, pp. 206-207. En Herce y sus aldeas de Las Vergasas y Santa Olalla vivían 300 vecinos, en Hornillos 42, en La Santa y sus aldeas 45, y en Torremuña y sus aldeas 70 . Todo el señorío sumaba 457 vasallos.

101 Diago Hernando, "Un monasterio cisterciense", pp. 142-144. Se hace mención expresa a las siguientes prestaciones: traer fusta tres días al año para el monasterio, labrar un día al año en la viña mayor, traer el pan de Torremuña y prestar otros servicios dos días al año donde les mandasen. 
sector de los vecinos de Herce, encabezado por el regidor Sebastián de Vidaurreta. Denunciaron estos vecinos que la abadesa y sus parientes les venían causando muchos agravios, llegando la primera a decretar el destierro de Sebastián de Vidaurreta, a quien prohibió que entrase en Herce y en su Tierra. A otro vecino llamado Diego de San Miguel, dado que tenía fama de poseer dinero, lo sometió a un registro de sus casas, en el que participó su hermano, don Alonso de Arellano, y que concluyó con la requisición de 600 reales de plata de los viejos y otras monedas, que quedaron en poder de la abadesa. Don Alonso de Arellano, además, había agredido a un alcalde de la villa, Juan Martínez, y le había quebrado la vara en la cabeza, tratando igualmente de atacar con una daga al cura dentro de la iglesia. Por fin, este mismo caballero había sometido a presiones a otro vecino, de elevada posición, llamado Fernán Velázquez, para que le cediese la antigua mezquita de los moros recientemente convertidos a la fe cristiana, de la que se le había hecho merced. Y, porque no se la quiso dar, le fueron cortadas las manos y fue llevado preso a la fortaleza de Clavijo, donde le tuvieron detenido en una mazmorra durante cincuenta días. Por fin, también se acusó a la abadesa de tener ocupados los ejidos del lugar, para darlos a censo y tributo a quien quería, y de meter sus ganados a comer impunemente en los términos de cereal y de viñedo ${ }^{102}$.

No hemos podido precisar la relación de parentesco existente entre este Sebastián de Vidaurreta, opuesto a la abadesa en 1507, y los hermanos Francisco y Miguel de Vidaurreta que, como ya indicamos en su momento, formaban parte en 1512 de una facción enfrentada a la misma abadesa y sus parientes del linaje Arellano. Es muy posible, no obstante, que exista una conexión entre los acontecimientos de ambos años, que probaría la presencia de una enquistada lucha de bandos en la villa de Herce, en uno de los cuales militaría la propia abadesa, mientras que el otro estaría encabezado por el linaje de los Vidaurreta, con importante proyección política en la villa de Herce y su comarca. Este enfrentamiento subyacente sería, por lo tanto, determinante para la caracterización del conflicto antiseñorial planteado en esta villa en este período, que, una vez más, no respondería al modelo de choque frontal entre la autoridad señorial y el conjunto de los vasallos en bloque.

Por otra parte, un interesante memorial sin fecha presentado ante las instituciones centrales de la monarquía por un tal Juan de Arellano en nombre del monasterio nos informa de otro episodio de orientación antiseñorial ocurrido en Herce sobre el que son muchos los interrogantes sin respuesta que se nos plantean. Se denuncian en él ciertas "fuerças e alborotos" en que habían participado muchos vecinos de la villa, "levantándose a manera de Comunidad". Otro memorial de este mismo Juan de Arellano acusaba a un regidor llamado Pedro Ibáñez de ser el principal inspirador de la rebelión. Pero no hemos podido precisar el momento en que los acontecimientos denunciados tuvieron lugar, por lo que nos resulta imposible realizar una valoración adecuada de los mismos ${ }^{103}$. Finalmente, el monasterio de Santa María de Herce, también denunció en ocasiones problemas para recaudar algunos de sus derechos señoriales. En concreto, en 1511, se comisionó al corregidor de Logroño para que asegurase a la abadesa el cobro de las 25 cántaras de vino de censo que el monasterio debía percibir por estar situadas sobre ciertas heredades de su propiedad ${ }^{104}$.

\footnotetext{
102 Provisión al corregidor de Logroño, AGS. RGS, VI-1507.

103 Diago Hernando, "Un monasterio cisterciense", pp. 144-145.

104 Comisión al corregidor de Logroño, AGS, RGS, XI-1511.
} 
Pero quizás la circunstancia que mayor singularidad confirió a esta comunidad de monjas cistercienses como titular de derechos señoriales fue que entre sus vasallos hubo un nutrido grupo de mudéjares asentados en la villa de Herce. En el reino de Aragón no fue infrecuente que mudéjares estuviesen sometidos a la jurisdicción de entidades eclesiásticas, pero no ocurrió así en la Corona de Castilla, y menos aún, por supuesto, entre los monasterios del Císter. Santa María de Herce fue, desde este punto de vista, una rara excepción. Y cabe decir que la presencia de población mudéjar en el señorío monástico colocó a la abadesa y monjas en ocasiones en posiciones incómodas o muy problemáticas. Ocurrió, por ejemplo, a comienzos del siglo XV, cuando el monasterio mantuvo conflictos con sus vasallos moros de Herce que le obligaron a requerir la intervención del señor de Cameros, Juan Ramírez de Arellano, y de su esposa, Isabel Enríquez, para que mediaran en su resolución ${ }^{105}$. Por su parte, en 1488 ocurrió un episodio que puso en evidencia hasta qué punto podía llegar a ser estrecho el trato humano entre las monjas cistercienses y los seguidores de la fe de Mahoma como consecuencia del ejercicio del señorío. Entonces un moro vecino de Herce, llamado Ali, tomó en arrendamiento la recaudación de las alcabalas de esta villa. Como consecuencia, según se reconoce en el documento, tuvo "algún trato y conversación " en el monasterio. Y esta circunstancia le facilitó el poder llegar a mantener relaciones sexuales con una monja llamada María de Palomeque, que como consecuencia de las mismas quedó embarazada y dio a luz una criatura. En castigo, la abadesa puso en cárcel perpetua a la monja, mientras que el moro huyó, y, para escapar a la acción de la justicia, se convirtió a la fe cristiana, adoptando el nombre de Jorge de Lezana ${ }^{106}$.

\subsection{Conflictos del monasterio cisterciense de San Prudencio con sus vasallos de Lagunilla}

El monasterio de San Prudencio de Monte Laturce ejercía la jurisdicción civil y criminal sobre la villa de Lagunilla, en la que, según la averiguación de 1553, había ciento cincuenta vecinos, entre los que se incluían clérigos y viudas. De ellos bastante menos de la mitad, en concreto cuarenta y dos, eran pecheros, que estaban sometidos a ciertas obligaciones específicas, de las que estaban excluidos los hidalgos. Se trataba en concreto de la entrega cada año al monasterio de 22 fanegas de cereal mediado y $60 \mathrm{mrs}$., de un yantar, entre todos ellos, y cada uno de por sí 12 mrs. y un real por cada yugada de mulas o bueyes, y seis azumbres de vino, o en su lugar 25 mrs., cada vecino pechero que tuviese casa dentro de la cerca de la villa. El único tributo que se entregaba por el conjunto de los vecinos agrupados en concejo consistía en dos conejos anuales o, en su lugar, dos reales, que se daban en razón de la caza ${ }^{107}$. Esta concentración de la presión fiscal señorial sobre los pecheros parece, sin embargo, que tuvo una contraprestación en el hecho de que lograron reservarse

105 Pérez Carazo, Santa María de Herce, pp. 392-393.

106 Comisión a las justicias para que capturen al converso Jorge de Lezana, AGS, RGS, V-1488, fol. 21.

107 Alonso Martín y Palacio Sánchez Izquierdo, Jurisdicción, gobierno y hacienda, pp. 205-206. A gran distancia de Lagunilla, por su importancia demográfica, se situaba el otro lugar sobre el que el monasterio ejercía la jurisdicción civil y criminal, Villanueva, que contaba con 12 vecinos, que eran vasallos solariegos y debían pagar anualmente cada uno 10 fanegas de trigo, una gallina y medio real, más un peón para trabajar en las heredades del monasterio en lo que les mandaren. 
el derecho a designar al único alcalde ordinario de la villa, mientras que los hidalgos quedaban incapacitados para designar otro.

Por este motivo, estalló en el tránsito del siglo XV al XVI un enconado conflicto entre los pecheros y los hidalgos de esta villa, durante el cual el abad y monjes hicieron causa común con los primeros. Entonces, en efecto, defendieron todos ellos, representados conjuntamente por un mismo procurador ante el Consejo Real, que la costumbre observada en la villa había sido elegir cada año un alcalde que fuese labrador vecino de la misma, con el acuerdo y consejo del abad y convento, quedando los hidalgos excluidos de poder desempeñar este cargo y de participar en el proceso de su elección. Los hidalgos, por su parte, habrían tratado de acabar con esta práctica, poniendo un segundo alcalde extraído de sus filas, desencadenando por este motivo el litigio. En defensa de su postura, los pecheros y los monjes argumentaron que los hidalgos, por el mucho favor que se les dispensaba en aquella comarca, les agraviaban de muchas maneras, y así lo habían venido haciendo en el pasado. Denunciaron que hacían ostentación de una actitud de abierta desobediencia a la autoridad señorial, puesto que, estando el monasterio en posesión de castigar en la villa y sus términos, y de ejecutar en personas y bienes las penas en que incurrían los condenados, "se habían alzado" y no consentían ser castigados por el abad ni por el único alcalde que ejercía la jurisdicción ordinaria ${ }^{108}$.

La parte de los hidalgos, sin embargo, presentó ante la monarquía un cuadro de la situación bastante diferente, poniendo el acento en la actitud hostil que hacia ellos mostraba el monasterio apoyado en sus vasallos pecheros. Su procurador Pedro Terrova denunció que el abad don Martín de Cirueña les quería impedir que eligiesen un regidor, para que desempeñase su oficio junto con el designado cada año por los pecheros, como habían tenido por uso y costumbre. Se lamentó también de que, pese a que los hidalgos eran más de sesenta y debían, por tanto, superar en número a los labradores pecheros, no podían ejercer el derecho a nombrar un alcalde. Y de esta circunstancia se derivaba que el alcalde, puesto por estos últimos, les hacía muchos "agravios y sinrazones", contando además para ello con el favor del abad. Por este motivo, los delitos que los pecheros cometían contra los hidalgos no eran castigados y, además, a estos se les imponían penas injustas. Asimismo, denunció que el abad desde la pasada Navidad había comenzado a tratar de llevar las "penas de la sangre", multas impuestas por infracciones de carácter criminal, pese a que se trataba de un derecho reservado al concejo. También que hacía entrar sus ganados a pastar en las dehesas que poseía el concejo, que debían ser guardadas para que pastasen en ellas los ganados mayores de los vecinos, no consintiendo que estos tomasen prendas a los que metían a pastar en ellas otros ganados, para poder quedarse él con todas las multas impuestas a los infractores ${ }^{109}$.

Los hidalgos de Lagunilla debían estar insatisfechos por la circunstancia de que, pese a su superioridad numérica, estaban relegados a una posición secundaria en las instituciones de gobierno local, al no poder participar en la designación de los oficiales de la justicia ordinaria y querérseles denegar incluso el derecho a nombrar un regidor. Como reacción, es probable que buscasen el fortalecimiento de su posición política mediante el establecimiento de relaciones clientelares con miembros

\footnotetext{
108 Esta tesis, defendida por Juan de Logroño, como procurador del abad, convento y vecinos y labradores de la villa de Lagunilla, ante el Consejo Real, está recogida en AGS, RGS, III-1501, fol. 431.

109 Comisión al corregidor de Logroño, AGS, RGS, III-1501, fol. 202.
} 
de la alta nobleza de la región, siempre inclinados a tratar de reforzar mediante este expediente su posición de poder. Así se deduce de la solicitud de carta de seguro que presentaron ante el Consejo Real a comienzos del año 1501 el abad y monjes de San Prudencio y los labradores de Lagunilla, con el argumento de que se temían de varias personas de la comarca que les tenían odio, enemistad y malquerencia. Entre ellos mencionaron explícitamente al duque de Nájera, don Pedro Manrique, a su hijo el conde de Treviño, don Antonio Manrique, al conde de Nieva, don Antonio de Velasco, y a otros varios hidalgos que es probable que estuviesen integrados en las redes clientelares de estos nobles titulados, como eran Alonso de Zúñiga, alcaide de Jubera, Juan de Fuenmayor, alcaide de Arnedo, Diego de Dávalos, alcaide de Ocón, y otros varios individuos no identificados por sus nombres, vecinos de Arnedo, Ocón, y de la propia villa de Lagunilla ${ }^{110}$. El que se solicitase esta carta de seguro precisamente en el momento en que se estaba siguiendo el pleito con los hidalgos sugiere que estos últimos se habían puesto en contra de sus señores los monjes porque sentían sus espaldas bien cubiertas con el apoyo que les podían prestar los nobles de la comarca. No obstante, tampoco lo debieron considerar suficiente, puesto que al igual que sus oponentes, también solicitaron al Consejo Real que expidiese a su favor carta de seguro, que les pusiese a salvo de agresiones por parte de aquéllos ${ }^{111}$.

Sobre la propensión de los representantes de la alta nobleza a inmiscuirse en los asuntos internos de los lugares de señorío monástico para ampliar sus bases de poder ya hemos tratado por extenso. Por lo que respecta a Lagunilla en particular, disponemos de indicios que sugieren que ya había sucumbido alguna vez en el pasado a sus ambiciones. En concreto, cabe destacar que en el período de desórdenes desencadenados como consecuencia de la guerra entre Pedro I y su hermanastro Enrique de Trastamara, esta villa camerana fue colocada bajo su encomienda, atendiendo a una petición de los propios monjes, por un representante de la nobleza media regional, Diego Fernández de Lezana ${ }^{112}$, quien también se hizo con el control por la misma vía de lugares pertenecientes al señorío de los monasterios benedictinos de San Millán de la Cogolla ${ }^{113}$ y Santa María de Nájera ${ }^{114}$. Bastante tiempo después, tras otro período de desórdenes, que cubrió la segunda mitad del reinado de Enrique IV, sabemos que Lagunilla estuvo bajo la encomienda de los Arellano, condes de Aguilar. Nos informa de ello Luis de Salazar y Castro, quien, al aludir al enfrentamiento banderizo que opuso a los Manrique con los Arellano en la Rioja, indica que en 1478 los vecinos de Clavijo, villa del conde de Aguilar, y los de Lagunilla, "que estavan en su

110 AGS, RGS, III-1501, fol. 430.

111 AGS, RGS, III-1501, fol. 189.

112 Así consta por provisión dirigida por Juan I a Diego Fernández de Lezana, publicada en García Turza, Documentación Medieval, doc. $\mathrm{n}^{\circ} 121$ (1380, diciembre 22. Medina del Campo). En dicha provisión se hace constar que "el qual dicho logar dixo que vos fuera dado en encomienda por los monges del dicho monasterio podía aver dies años, quando eran las guerras, estando el dicho monasterio sin abad (...). La qual dicha encomienda del dicho logar de Laguniella, dixo que vos dieran porque guardassedes et defendiesedes al dicho logar e les non echassedes pechos nin pedidos".

113 Sobre la ocupación de Camprobín por Diego Fernández de Lezana al monasterio de San Millán, informa una provisión de Juan I dada en Medina del Campo el 26 de septiembre de 1380, en AHN, Clero, leg. 3.083, a la cual alude Serrano, Cartulario, p. 105.

114 Sobre la ocupación por Diego Fernández de Lezana de Leza y Ribafrecha al monasterio de Santa María de Nájera informa una provisión de Juan I dada en Medina del Campo el 22 de diciembre de 1380, en AHN, Códices, 106-B, fol. 336. 
encomienda", corrieron el término de Ribafrecha y robaron sus ganados, "estando en la encomienda del duque" 115 .

El recuerdo de estos episodios de sometimiento de Lagunilla a poderosos miembros de la nobleza riojana en períodos de inestabilidad política es probable que influyese en el ánimo de las partes contendientes en el conflicto que opuso en la villa a hidalgos y labradores pecheros en el tránsito del siglo XV al XVI. Dicho recuerdo debía alimentar la desconfianza existente en la comunidad monástica hacia los hidalgos, que serían percibidos como valedores de los poderes nobiliarios de la comarca, ansiosos de ampliar su poder a costa de los señoríos monásticos. Y ello contribuiría a explicar la alianza establecida entre el abad y convento y sus vasallos pecheros. Desafortunadamente no sabemos, sin embargo, cuál fue el desenlace de este singular episodio de conflicto antiseñorial, en el que intervino como juez pesquisidor el corregidor de Logroño ${ }^{116}$.

De lo que sí tenemos certeza es de que las tensiones entre la comunidad monástica y determinados sectores de la población de Lagunilla continuaron e incluso se agravaron por la aparición de un nuevo factor, las disputas por el control de la abadía asociadas a los intentos de introducción de la reforma observante. Los cambios en la identidad de quienes presidieron por estos años de tanta inestabilidad la comunidad monástica influyeron, en efecto, sobre el sesgo que tomaron las relaciones del monasterio con sus vasallos, que experimentaron bruscos virajes. Así, mientras que bajo Martín de Cirueña en 1500 se había fraguado una sólida alianza entre el poder abacial y el estamento de los labradores, en 1506 la situación aparece radicalmente invertida. Buena prueba de ello es que el mismo Juan de Logroño, que en 1500 había representado a la parte del abad y los pecheros ante la monarquía, denunciando los abusos de los hidalgos, en 1506 había pasado a convertirse en víctima del nuevo poder abacial. En concreto, en una carta de comisión para el corregidor de Logroño fechada en septiembre de 1506, se recoge la siguiente denuncia presentada por el concejo de Lagunilla, a iniciativa sin duda del estamento de los pecheros. Se quejaba de que, habiendo estado en uso de nombrar un alcalde que fuese labrador, quien ejercía la jurisdicción civil y criminal en primera instancia, aquel año de 1506, el abad, quebrantando dicha costumbre, había prohibido bajo grandes penas al elegido que usase el oficio. Le había obligado a que entregase la vara a un tal Fernán Marín, que él había nombrado directamente, usurpando de este modo la jurisdicción al concejo. Además, al anterior alcalde, que era precisamente el mencionado Juan de Logroño, lo había tenido preso, y le había embargado sus bienes por el simple hecho de haber ejercido su oficio. A otros vecinos los había llevado presos al monasterio con "quillos", y a todos estos abusos y fuerzas se sumaban reiterados intentos de aumentarles los tributos ${ }^{117}$. Por todo ello, el concejo solicitó a la monarquía que expidiese carta de seguro que pusiese a salvo a los vecinos de las agresiones del poder abacial. En esta ocasión, sin embargo, no cabe duda de que fueron los pecheros los inspiradores de dicha solicitud, a diferencia del año 1500, cuando solicitaron conjuntamente con el abad y monjes carta de seguro frente a agresiones de los hidalgos ${ }^{118}$.

\footnotetext{
115 Salazar y Castro, Historia Genealógica, t. I, libro V, capítulo X, p. 388.

116 A fines de 1501 el procurador de los hijosdalgo de Lagunilla denunció ante el Consejo Real que Diego de Enciso, escribano de Logroño, ante el que había pasado la pesquisa, les había llevado derechos excesivos, en AGS, RGS, XI-1501, fol. 181.

117 Comision al corregidor de Logroño, AGS, RGS, IX-1506.

118 La carta de seguro para los vecinos de Lagunilla en AGS, RGS, IX-1506.
} 
No queda clara la identidad del abad con el que habían pasado a estar enfrentados Juan de Logroño y los demás miembros del estamento pechero en 1506. Parece probable que se trate de Martín de Moreda, último abad claustral de San Prudencio, que poco antes de 1505 había renunciado a su abadía para facilitar la implantación de la reforma observante, pero que, al poco tiempo, dio marcha atrás y maniobró en corte romana para lograr que se le restableciese como abad perpetuo, en un primer momento con éxito ${ }^{119}$. De hecho la documentación nos confirma que este abad tenía establecidos fuertes vínculos de amistad e incluso de parentesco con miembros de la nobleza de la región, por lo que parecía más proclive a entenderse con los hidalgos que el Martín de Cirueña que chocó con ellos frontalmente en 1500. Así, en concreto, sabemos que un hidalgo llamado Juan de Fuenmayor, avecindado en la villa de Albelda, del señorío de los condes de Aguilar, había casado con una sobrina suya y había puesto en su poder grandes cantidades de dinero. Precisamente este hidalgo fue denunciado por haber ocupado, con apoyo de un hijo del conde de Aguilar, llamado Juan Ramírez de Arellano, muchos términos pertenecientes al monasterio de San Prudencio ${ }^{120}$. Y más adelante se le acusó de haberse apoderado, con el apoyo de su pariente el alcaide de Arnedo, Pedro Díaz de Fuenmayor, y del propio señor de esta villa, el conde de Nieva, de la granja de San Bartolomé de Noguera, arrebatándosela a los monjes observantes de San Prudencio ${ }^{121}$.

El conflicto desatado entre claustrales y observantes, al que nos hemos referido con anterioridad, forzó como vimos a la monarquía a intervenir, poniendo el monasterio bajo el gobierno de un laico, el escribano logroñés Martín López de Salvatierra. Nos consta que las relaciones que los pecheros de Lagunilla, y muy en particular su dirigente Juan de Logroño, mantuvieron con este administrador laico fueron muy tensas, por su parcialidad a favor del abad, del que se dice que era primo hermano. Así, en concreto en 1511, Juan de Logroño presentó una denuncia ante la monarquía, desacreditando a Martín López de Salvatierra como "persona de liviana opinion", que "consume y maltrata los bienes de la Orden, y causa muchos agravios y vejaciones a los vasallos de ella", y que por ser primo hermano del abad que entonces tenía la abadía, "son ambos a dos una misma cosa". También denunció que había tenido preso a su padre en el cepo, a pesar de tratarse de un hombre viejo, de setenta años de edad ${ }^{122}$. Otro vecino de Lagunilla, que en este mismo año presentó graves acusaciones contra Martin López de Salvatierra, fue Juan de Comparada, quien coincidió en la denuncia de que por ser primo hermano del abad favorecía abiertamente sus intereses. Además se quejó de que hacía dos años el abad había ordenado apresar a un pariente de su mujer, por haber litigado con él, y lo hizo meter en un aljibe del monasterio. Por temor a que procediese también contra él, huyó de la villa, mientras el abad aprovechó para hacerle tomar un par de acemilas de labor, y a su mujer unas casas, un palomar y unas viñas, valorado todo en más de 200.000 mrs. Además, ha-

119 Sobre el enfrentamiento que se desató entre observantes y claustrales en San Prudencio tras la muerte de Isabel la Católica, período durante el que fray Martín de Moreda trató de recobrar el cargo de abad al que había renunciado para facilitar la reforma, véase Diago Hernando, "La reforma de los monasterios", pp. 680-682.

120 AGS, RGS, V-1505, fol. 231.

121 AGS, RGS, XI-1507. Con anterioridad, fray Gregorio de Madrid, en nombre del abad observante, había acusado a fray Pedro de Ribafrecha, monje claustral, de haber tomado por la fuerza junto con otros hombres seglares la granja de La Noguera, para impedir la reforma del monasterio, en Provisión al corregidor de Logroño, AGS, RGS, VII-1506.

122 Comisión al corregidor de Logroño para que averigüe sobre la denuncia de Juan de Logroño, AGS, RGS, VIII1511. 
biendo sembrado en un lugar del señorío del conde de Nieva que era dezmero de San Prudencio, le había hecho tomar por la fuerza 200 fanegas de cereal que allí tenía ${ }^{123}$.

Durante el tiempo en que el escribano Martín López de Salvatierra tuvo en sus manos la administración del monasterio de San Prudencio nos consta, además, que se tomaron decisiones en contra de los intereses políticos de los labradores pecheros. En concreto, por una provisión dirigida a los hidalgos de Lagunilla en enero de 1512 sabemos que estos habían elegido entre ellos un alcalde, que fue confirmado por el referido administrador en nombre del monasterio, amparándose en una sentencia que previsamente se había pronunciado, por la que se ordenaba que se eligiesen para el oficio de alcaldía de la villa los vecinos que fuesen más hábiles y suficientes ${ }^{124}$. De este modo quedaba anulado el tradicional procedimiento de designación del único alcalde de la villa, que reservaba a los pecheros el derecho a elegirlo entre los miembros del estamento, con exclusión de los hidalgos. Por ello, comprensiblemente, el concejo, dando voz a los pecheros, apeló de la sentencia que había permitido que se les privase de su derecho consolidado a designar al alcalde.

Desconocemos cómo se resolvió la disputa en torno al control de la abadía entre fray Martín de Moreda, y el abad y monjes observantes. Lo cierto es que varios años después el primero había ya desaparecido definitiamente del escenario, quizás por haber muerto, y un nuevo abad, fray Bernardo de Valladolid, volvió a entrar en conflicto con sus vasallos de Lagunilla. Esta vez, sin embargo, como había ocurrido en tiempos de fray Martín de Cirueña, el enfrentamiento se planteó de nuevo con los hidalgos. La documentación nos informa sobre el conflicto cuando se hallaba en plena ebullición a medidados de la década de 1520, y hacía ya seis años que fray Bernardo de Valladolid desempeñaba el cargo de abad. Buena prueba de que las relaciones que este mantenía con los vecinos de Lagunilla eran sumamente tensas la proporciona la concesión a estos de una carta de seguro en abril de 1524 , porque se temían de él125. Al año siguiente, en abril de 1525, se expidió una carta de comisión al corregidor de Logroño a petición de Pedro Martínez de Terrova y otros vecinos de Lagunilla. Dada la coincidencia en el nombre, resulta plausible que se trate del mismo individuo que en 1500 había actuado como procurador de los hidalgos frente al abad Martín de Cirueña. También podría tratarse de un hijo suyo. En cualquier caso, de sus denuncias se deduce que la tensión había vuelto a presidir una vez más las relaciones del monasterio con sus vasallos. En concreto acusó al abad de cometer muchos "agravios, extorsiones y tiranías" contra los vecinos de la villa, llevándoles penas exorbitantes, desterrando a algunos de ellos y tomando represalias contra los que acudían a la Chancillería a denunciar. Más en concreto le acusó de consentir que el clérigo que ocupaba el curato del lugar estuviese amancebado públicamente, habiendo engendrado con sus mancebas hasta ocho hijos ${ }^{126}$. Sería preciso disponer de alguna otra fuente documental complementaria para conocer más en profundidad el origen de estas tensiones, y los motivos por los que tanto el abad como el clérigo acusado de amancebamiento chocaron en esta ocasión con algunos de los hidalgos más influyentes de la villa de Lagunilla. Pero, como quiera que sea, interesa destacar que veinticinco años después había vuelto a replantearse con todo su vigor el con-

\footnotetext{
23 AGS, RGS, IX-1511.

AGS, RGS, I-1512.

AGS, RGS, IV-1524 (2 $2^{\circ}$.

26 Comisión al corregidor de Logroño a petición de Pedro Martínez de Terrova, AGS, RGS, IV-1525.
} 
flicto entre abad e hidalgos que se había visto apaciguado durante los años en que el monasterio había estado controlado por individuos con estrechos vínculos de parentesco con nobles de la comarca. La implantación definitiva de la reforma observante es un factor que no se puede dejar de tener en cuenta para explicar esta circunstancia.

\subsection{Resistencia antiseñorial en los lugares del monasterio de Santa María de Cañas}

Particularmente afectado por la actitud rebelde de muchos de sus vasallos se vio a comienzos del siglo XVI el monasterio de Santa María de Cañas, que, como hemos adelantado, venía manifestando evidentes síntomas de debilidad desde comienzos del siglo XV por la progresiva pérdida de su capacidad de control sobre su patrimonio. La situación más extrema se vivió en el lugar de Negueruela, donde, según denuncia presentada en 1513 por el procurador de la abadesa y convento, sus vecinos hacía dos años que habían proclamado que no se consideraban vasallos del monasterio, sino de la Corona Real, y habían dejado de abonar las rentas. Además, para reforzar su posición, habían tomado al conde de Nieva como encomendero, pese a que no lo podían hacer sin licencia de su señora la abadesa ${ }^{127}$. Semejante grado de tensión mostraban las relaciones del monasterio con sus vasallos de Matute, aunque, en este caso, paradójicamente, uno de los motivos que más contribuía a enturbiarlas no era el recurso de los vasallos a tomar por su cuenta un encomendero que les amparase. Todo lo contrario, eran estos los que temían que la abadesa y monjas pudiesen imponerles uno en contra de su voluntad. En efecto, en 1491, el representante de los vecinos de esta villa, que había sido entregada en señorío al monasterio por Alfonso X, manifestó su temor a que la abadesa "los querrá dar a algunos caballeros de la comarca", y que estos "los querrán tomar y tener contra su voluntad en encomienda, y les fatigarán y harán algunos agravios, no lo pudiendo ni debiendo hacer, por estar defendido por las leyes de estos reinos"128.

Con anterioridad, por otro lado, este monasterio de monjas cistercienses había tenido que hacer frente a la negativa de los vecinos de Hormilleja a satisfacer la renta en cereal que le debían. En concreto, en 1489, la abadesa denunció ante la monarquía que dichos vecinos, a los que calificó como sus vasallos, estando obligados a entregar todos los años entre 500 y 600 fanegas de cereal aproximadamente, se estaban negando a hacerlo, aunque eran requeridos para ello ${ }^{129}$. Las desavenencias entre las dos partes parece que derivaban de la pretensión de los vecinos de Hormilleja de aprovechar las tierras que el monasterio poseía en el lugar en unas condiciones ventajosas, que la abadesa y monjas no estarían dispuestas a admitir. Así se deduce de una carta de emplazamiento dirigida el año anterior a estas últimas a petición de Pedro el Rico y sus consortes, vecinos de Hormilleja, quienes se habían presentado en apelación de una sentencia dada contra ellos por el obispo de Segovia como juez comisionado por los reyes, por la que había declarado nulo cierto contrato de censo perpetuo otorgado entre ambas partes, y había condenado a Pedro el Rico y consortes a que devolviesen al monasterio la granja de Hormilleja y Ruego ${ }^{130}$. La negativa a entregar el medio millar de fanegas de cereal denunciada por el monasterio en 1489 sería, por consiguiente, una secuela de este litigio, que desconocemos en detalle

\footnotetext{
127 Comisión al corregidor de Santo Domingo de la Calzada, AGS, RGS, IX 1513.

128 Carta de amparo a los vecinos de Matute, AGS, RGS, III-1491, fol. 348.

129 AGS, RGS, II-1489, fol. 291.

130 AGS, RGS, VII-1488, fol. 112.
} 
cómo se resolvió. En cualquier caso, pone de manifiesto las dificultades que afrontaba este monasterio para sacar provecho de su patrimonio señorial, que en el caso de Hormilleja tenía un componente estrictamente solariego, sin atribuciones jurisdiccionales $^{131}$. Por otro lado, no fueron solo los campesinos los que le crearon dichas dificultades, puesto que, sin dejar el caso de Hormilleja, constatamos que varios años más tarde los intereses del monasterio de Cañas chocaron allí con los del monasterio jerónimo de Santa María de la Estrella, con el que pleiteó por razón del cereal de los diezmos debidos por las tierras cultivadas en el término de dicho lugar ${ }^{132}$.

En conclusión, los conflictos antiseñoriales a los que tuvieron que hacer frente los monasterios riojanos muestran un perfil muy diversificado, porque muy diversas eran también las características de los derechos señoriales que los mismos tenían reconocidos. Basta comparar los casos de los dos monasterios cistercienses femeninos. Por un lado, el de Santa María de Herce ejercía amplias atribuciones jurisdiccionales, en lo civil y en lo criminal, sobre un compacto conjunto de lugares. Por el otro, Santa María de Cañas solo tenía reconocidos derechos señoriales inseguros y mal definidos, de origen eminentemente solariego, sobre lugares dispersos.

Prácticamente todos los monasterios tuvieron que hacer frente a resistencias antiseñoriales, pero que en cada caso adoptaron perfiles singulares, en consonancia con las peculiaridades de cada señorío. Esta proliferación de las resistencias no cabe atribuirla, sin embargo, a la dureza del régimen señorial en estos lugares dependientes, total o parcialmente, de los monasterios. Desde este punto de vista, el contraste con las tierras del Imperio es notable. Más bien cabría concluir que las tensiones proliferaron como consecuencia de la propia debilidad política de los monasterios, de la que trataron de aprovecharse tanto sus vasallos como los nobles del entorno. Pero cuando los vasallos se vieron en la tesitura de tener que elegir entre permanecer sometidos a los monasterios o entrar bajo la dependencia más dura de algún miembro de la nobleza, no dudaron en inclinarse por la primera opción. Lo confirma el caso de Torrecilla de Cameros, que denunció el intento del monasterio de Santa María de Nájera de vender el señorío sobre la villa al duque de Nájera. En la misma línea apunta la queja de la villa de Matute, preocupada por que el monasterio de Cañas la entregase a la encomienda de algún noble de la comarca.

\section{Incidencia de la guerra comunera sobre los monasterios}

La inestabilidad vivida por el conjunto de la Corona de Castilla durante las dos primeras décadas del siglo XVI llegó a su culminación en los años 1520 y 1521, con el estallido de la revuelta que dio inicio a la llamada guerra de las Comunidades. Los desórdenes y episodios de violencia se generalizaron entonces por todo el reino, aunque con mayor intensidad en unas regiones que en otras. La Rioja, aunque no

131 Según la averiguación de 1553, en Hormilleja la jurisdicción civil y criminal la ejercía la ciudad de Nájera. Había 15 vecinos, que eran solariegos del monasterio, y pagaban cada año 400 fanegas de pan mixto y el diezmo, más 400 mrs.y 4 pares de capones, entre todos los vecinos, "de pecho y señorío" (Alonso Martín y Palacio Sánchez Izquierdo, Jurisdicción, gobierno y hacienda, p. 208).

132 Provisión al maestrescuela de Santo Domingo de la Calzada, juez conservador del monasterio de la Estrella, para que acepte la apelación presentada por el monasterio de Cañas a la sentencia pronunciada en el pleito que trataba con dicho monasterio jerónimo sobre cierto cereal de los diezmos del término de Hormilleja, AGS, RGS, XI-1519. 
figuró entre los principales escenarios donde se dirimió el conflicto, tampoco se vio libre de sus efectos. Así, entre los sucesos de más gravedad que se desencadenaron en la región en aquella coyuntura cabe destacar los levantamientos antiseñoriales, en especial el de la ciudad de Nájera contra su señor el duque, que tuvo que regresar apresuradamente desde Navarra, donde desempeñaba el cargo de virrey, para reprimirlo ${ }^{133}$. Por el contrario, las ciudades realengas no adoptaron una actitud decidida de apoyo a la causa rebelde, aunque tampoco había en la región ninguna con derecho a enviar procurador a Cortes, lo cual mermó su protagonismo en la Santa Junta, a la que solo enviaron delegados las ciudades con voto en Cortes.

Los monasterios, dada su imbricación en las estructuras políticas regionales, tampoco pudieron mantenerse al margen. Se vieron particularmente afectados algunos con lugares de señorío próximos a Nájera, en los que cundió el ejemplo sentado por esta ciudad al levantarse contra su señor el duque. En primer lugar, destaca el caso del monasterio benedictino de Santa María de Valvanera, que vio cómo las tensas relaciones que venía manteniendo con sus vasallos de la villa de Anguiano empeoraron aún más, al levantarse estos en comunidad, obligando al propio condestable a acudir en persona para aplacar los ánimos, aunque con un éxito solo relativo, puesto que el enfrentamiento prosiguió de forma más soterrada ${ }^{134}$. También se vio directamente afectado el monasterio de San Millán de la Cogolla, puesto que sus vasallos del Valle de San Millán, contra los que había estado litigando en las décadas previas, se alzaron por la comunidad y pusieron por su cuenta alcaldes, alguaciles y merinos, alistando gentes de armas. Los sublevados derribaron las puertas de un edificio del monasterio llamado El Nogueral, pero, cuando recibieron una carta del condestable ordenándoles que tornasen las varas de la justicia a su señor el abad, acataron la orden, atemorizados seguramente por las duras represalias impuestas por el duque de Nájera a sus vasallos rebeldes. Y acto seguido el abad les concedió el perdón, con la única condición de que reconstruyesen las tapias del Nogueral derribadas ${ }^{135}$. No se tiene noticia, sin embargo, de que el monasterio de Santa María de Nájera se viese afectado por los desórdenes que ocurrieron en la ciudad donde se ubicaba. Ni tampoco sus lugares de señorío, muy en particular Torrecilla de Cameros, aprovecharon la ocasión para librarse de su sometimiento a la autoridad monástica, con la que esta villa venía manteniendo una muy tensa relación. Seguramente el precedente sentado con las negociaciones entre el monasterio y el duque de Nájera, para venderle a este el señorío sobre la referida villa, disuadió a los vecinos de Torrecilla de arriesgarse, para no proporcionar una excusa al monasterio para dirigirse de nuevo al duque en solicitud de ayuda para reprimir a sus vasallos.

Por lo demás, al margen de favorecer los levantamientos antiseñoriales, la guera comunera también creó condiciones propicias para que en determinadas comunidades benedictinas y cistercienses se relajase la disciplina entre los monjes, en particular entre aquellos que no habían acogido de buen grado la introducción de la reforma observante. La documentación proporciona testimonios relativos a monjes cistercienses que aprovecharon los desórdenes para escapar de los monasterios y andar "fuera de orden", y también sobre alteraciones en el monasterio benedictino de San Salvador de Oña ${ }^{136}$. Pero, por lo que respecta a los monasterios riojanos, no

133 Los levantamientos de Nájera y Haro son analizados en el contexto de los movimientos antiseñoriales durante las Comunidades por Gutiérrez Nieto, Las Comunidades. Véase también Maldonado, "La Rioja en la Guerra".

134 Diago Hernando, "Los conflictos antiseñoriales" y Gutiérrez Nieto, Las Comunidades, p. 163.

135 Peña, Páginas, p. 198.

136 Diago Hernando, "El factor religioso", pp. 128-130. 
disponemos de noticias documentales que indiquen que en ellos se reprodujeron este tipo de situaciones, que, por el contrario, habían proliferado durante las dos primeras décadas del siglo XVI, como hemos puesto de manifiesto en el presente trabajo.

Sí nos consta, en cualquier caso, que la inestabilidad reinante en estos años de guerra exacerbó los conflictos preexistentes y favoreció que estos adoptasen un perfil más violento. Ocurrió en el caso de los enfrentamientos que el monasterio de San Prudencio mantenía con la villa de Clavijo, del señorío de una rama cadete de los Arellano. Las tensiones entre ambas partes ya se venían manifestando desde hacía tiempo. Así, en 1514, el monasterio había denunciado que el lugar de Clavijo agraviaba a los monjes y a sus familiares, no dejándoles cortar leña en el monte Rebollar, ni pastar con sus ganados en los términos, a pesar de que tenían adquirido derecho de posesión inmemorial a hacerlo ${ }^{137}$. De nuevo en 1517 se quejó de que los de Clavijo habían tomado prendas a los ganados del monasterio y habían llevado presos a unos criados suyos que estaban cortando leña ${ }^{138}$. La tensión generada por este motivo llevó entonces al monasterio a solicitar carta de seguro $^{139}$. Finalmente parece que, tras muchas dilaciones, el corregidor de Logroño, licenciado Juan Moreno, pronunció sentencia a su favor, prohibiendo que se tomasen prendas a personas dependientes del mismo en término de Clavijo, de la cual apeló el señor de esta villa, Alonso de Arellano en marzo de $1521^{140}$. Para cuando se presentó esta apelación, sin embargo, parece que los de Clavijo, aprovechando la situación de inestabilidad que vivía el reino, habían decidido tomarse la justicia por su mano, recurriendo al uso de la fuerza bruta. Así lo denunció Diego de Fuentepinilla en nombre de San Prudencio. Según su versión, en un día de febrero de 1521 fue todo el pueblo de Clavijo al monasterio "con mucha furia y enojo, armados a manera de alboroto y escándalo, a repique de campana". Quebrantaron las puertas de las huertas del monasterio y sacaron de allí toda la leña que tenía para su provisión, además de unas 300 cabezas de ganado ovino. En otra jornada, acudieron de nuevo con ballestas y lanzas, cercaron el monasterio y derribaron las tapias, impidiendo que saliese nadie de allí ${ }^{141}$.

Este tipo de explosiones de violencia no eran inusuales en los conflictos entre lugares colindantes por el usufructo de términos que se consideraban comunales. Pero la gravedad de las actuaciones de los de Clavijo en febrero de 1521 se explica por razón de la inestabilidad que la revuelta comunera había generado, que impulsaría a muchos a proceder de forma más temeraria, en la confianza de que las instituciones de gobierno de la monarquía estaban demasiado debilitadas para restablecer de forma inmediata el orden y castigar con contundencia a los transgresores.

\section{Conclusión}

Tras el intermedio de inestabilidad por el que atravesaron los monasterios de la Rioja en las primeras décadas del siglo XVI, la calma fue volviendo progresivamente a estas comunidades. En la mayoría de ellas terminó adoptándose la reforma observante,

137 Comisión al corregidor de Logroño, AGS, RGS, VIII-1514.

138 Comisión al corregidor de Logroño, AGS, RGS, XII-1517, con referencia a la prórroga de la comisión en AGS, RGS, V-1518.

139 AGS, RGS, VI-1518.

140 Emplazamiento al abad de San Prudencio, comunicándole la apelación presentada por Alonso de Arellano, AGS, RGS, III-1521.

141 Comisión al corregidor de Logroño, AGS, RGS, VIII-1521. 
que contribuyó a apartarlas del involucramiento en los asuntos seculares que tanto había contribuido en el pasado a desestabilizarlas. Esta reorientación también fue facilitada por la venta de parte de su patrimonio señorial, puesta en marcha con consentimiento papal por la nueva dinastía de los Habsburgo. Pero este proceso, en el caso de la Rioja, no ha sido todavía analizado con detalle por los investigadores, por lo que no resultan del todo bien conocidas sus consecuencias ${ }^{142}$. Nuevas investigaciones deberán iluminar este aspecto mal conocido de la historia monástica riojana.

Desde una perspectiva comparativa, cabe afirmar que los monasterios de la Corona de Castilla lograron superar esta fase crítica de su historia con mayor fortuna que los de otros ámbitos de Europa, que por estas mismas fechas se vieron afectados por graves perturbaciones. Caso emblemático es el de los monasterios del Imperio, pues por un lado muchos no lograron sobrevivir a este período y terminaron siendo disueltos. Pero incluso los que corrieron mejor suerte y sobrevivieron, muy en particular en las tierras de la Alta Alemania más afectadas por la guerra Campesina, debieron extraer importantes lecciones de las experiencias vividas desde 1517, y se vieron obligados a afrontar el futuro con mucha más prevención e inseguridad.

El resultado del período de inestabilidad vivido por Europa a principios del siglo XVI podía haber sido muy diferente para todos. En primer, lugar cabe advertir que los monasterios fueron tempranamente disueltos en ámbitos en los que en décadas anteriores nada apuntaba a que tal desenlace fuese a tener lugar, aunque a posteriori en muchos casos la historiografía ha interpretado el fenómeno como inexcusable. Así, por ejemplo, no debemos olvidar que el monarca inglés, que en 1536 puso en marcha la más ambiciosa empresa de desamortización de la propiedad eclesiástica en favor de la monarquía centralizada hasta entonces acometida, había sido celebrado no hacía mucho tiempo como principal campeón de la fe católica. Por su parte, en el Imperio, donde muchos monasterios desaparecieron en el transcurso del siglo XVI, mientras que otros lograron pervivir hasta los primeros años del siglo XIX, conservando una relativa autonomía política y extensos patrimonios, tampoco el desenlace de los distintos procesos estaba predeterminado. Incluso en los ámbitos en que la nueva fe luterana se impuso con más facilidad nos encontramos con fenómenos paradójicos. Baste con una breve referencia al caso de la ciudad hanseática de Lübeck.

Muy pocos años antes de que se iniciase el proceso de la Reforma protestante había tenido lugar allí la fundación de una nueva comunidad monástica, en la que la iniciativa había partido de la propia sociedad política laica, al margen de los habituales cauces eclesiásticos. El origen de todo el proceso había estado en la iniciativa del duque de Mecklenburg de imponer la observancia en los monasterios del ducado. Este proyecto, que endurecía las condiciones de vida de las monjas, afectaba directamente a muchas mujeres procedentes de familias acomodadas de Lübeck que habían profesado en dichos conventos. Ni ellas ni sus familias se mostraron dispuestas a aceptar que se les impusiesen los exigentes modelos de vida propiciados por la reforma observante. Por ello, como reacción, las principales familias de Lübeck finalmente tomaron la decisión de promover la fundación de un nuevo convento en la propia ciudad, en el que pudiesen profesar las mujeres que optasen por la vida contemplati-

142 Una visión global sobre las desamortizaciones de señoríos eclesiásticos para el siglo XVI en Moxó, "Las desamortizaciones". Existe un trabajo monográfico dedicado a las ventas de señoríos eclesiásticos en el territorio de la actual comunidad autónoma de Castilla y León, que, por lo tanto no toma en consideración los riojanos, en Faya Díez, "La venta de señoríos". 
va y de oración, sin tener que padecer las duras condiciones de vida que se trataban de imponer en los conventos reformados del vecino ducado de Mecklenburg. Así, en 1502, numerosos ciudadanos se dirigieron a la máxima autoridad municipal, el Rat, para solicitar que se procediese a la fundación de un nuevo convento de monjas. La iniciativa, pese a su irregularidad, al realizarse al margen de los habituales canales eclesiásticos, prosperó. Y de este modo, por iniciativa municipal, se fundó el convento de Santa Ana, que fue favorecido con donaciones por las principales familias de la ciudad. Fue uno de los conventos de más corta vida en la historia del Imperio, pues en 1530 los mismos ciudadanos que habían auspiciado su fundación decretaron su disolución, en aplicación de los principios de la teología protestante que justificaron la desaparición de otras muchas comunidades monásticas centenarias ${ }^{143}$.

Los monasterios riojanos no siguieron la suerte de muchos de sus iguales en el Imperio o en Inglaterra porque contaron con el apoyo de una monarquía fuerte y centralizada, que, pese a sus constantes tensiones con el papado, estaba comprometida con el mantenimiento de la fe católica. Pero, como consecuencia, quedaron colocados en una relación de mayor dependencia respecto a dicha monarquía, que les obligó a hacer importantes concesiones, entre las cuales la más notoria fue la renuncia a una parte importante de su patrimonio señorial, puesto a la venta, con autorización pontificia, para financiar las crecientes necesidades de la Real Hacienda. Lo que ocurrió en los monasterios riojanos en las primeras décadas del siglo XVI pone bien en evidencia hasta qué punto las comunidades monásticas se adentraron en este período por una senda de progresiva dependencia respecto a la autoridad monárquica. Al enviar sus comisionados para que se hiciesen con el control por la fuerza de los edificios monásticos de Santa María de Nájera, San Millán de la Cogolla y San Prudencio de Monte Laturce, y los mantuviesen bajo su gobierno y administración durante muchos meses, la monarquía castellana, encarnada en la persona de Fernando el Católico, sentó un importantísimo precedente para el futuro de estas comunidades. A los monjes y a todos los miembros de la sociedad política regional se les quiso impartir una cristalina lección, mostrándoles que en el futuro las cosas no podrían continuar siendo igual, después de las turbulencias vividas. La suerte de los monasterios quedó estrechamente unida a la de la monarquía, y ello explica que, a principios del siglo XIX, entre los más comprometidos valedores del absolutismo figurasen los miembros de las comunidades monásticas que, al perder el apoyo de los reyes, se vieron abocados a la desaparición de la escena sociopolítica.

\section{Bibliografía}

Alonso Martín, María Luz, y Palacio Sánchez-Izquierdo, María Luisa, Jurisdicción, gobierno y hacienda en el señorío de abadengo castellano en el siglo XVI. Edición y estudio de las informaciones de Carlos V de 1553, Madrid: Editorial Complutense, CSIC, 1993.

Baury, Ghislain, Les religieuses de Castille. Patronage aristocratique et ordre cistercien (XIIe-XIIIe siècles), Rennes: Presses Universitaires de Rennes, 2012.

Blickle, Peter, Die Revolution von 1525, Múnich, Viena: Oldenbourg, 1975.

- Reformationund kommunaler Geist:DieAntwortder Theologen aufden Verfassungswandel im Spätmittelalter, Munich: Stiftung Historisches Kolleg, 1996.

143 Rüther, Prestige und Herrschaft, pp. 158-167. 
Blickle, Peter, Buszello, Horst, y Endres, Rudolf (eds.). Der deutsche Bauernkrieg, Stuttgart: UTB, 1995.

Cantera Montenegro, Margarita, "La comunidad monástica de Santa María de Nájera durante la Edad Media”, En la España Medieval, 36 (2013), pp. 225-262.

- Colección documental de Santa María de Nájera, siglo XV. Regesta Documental, Logroño: Instituto de Estudios Riojanos, 2011.

- "Viaje a Roma de un prior de Santa María de Nájera (Siglo XV)", Berceo, 164 (2013), pp. 325-341.

Diago Hernando, Máximo, "Un monasterio cisterciense femenino en tierras riojanas. Herce entre los siglos XIII y XVI”, Cistercium, 188 (1992), pp. 142-144.

- "La reforma de los monasterios riojanos en tiempo de los Reyes Católicos", Hispania Sacra, 90 (1992), pp. 680-682.

- "El intervencionismo nobiliario en los monasterios riojanos durante la Baja Edad Media. Encomiendas y usurpaciones", Hispania, 182 (1992), pp. 811-61.

- "Los señoríos monásticos en la Rioja bajomedieval: introducción a su estudio", Berceo, 131 (1996), pp. 85-107.

- "El poder de la nobleza en los ámbitos regionales de la Corona de Castilla a fines del Medievo: Las estrategias políticas de los grandes linajes en la Rioja hasta la revuelta comunera", Hispania, 223 (2006), pp. 501-546.

- "Los conflictos antiseñoriales en la Rioja en las décadas previas al estallido de la guerra de las Comunidades", Berceo, 152 (2007), pp. 37-77.

- "Las comarcas castellanas fronterizas con Navarra ante la conquista del reino en 1512", Príncipe de Viana, 242 (2007), pp. 917-945.

- "El factor religioso en el conflicto de las Comunidades de Castilla (1520-1521). El papel del clero", Hispania Sacra, 119 (2007), pp. 85-140.

- "Nobleza y reforma monástica en la Castilla tardomedieval. El papel de los duques de Nájera en los monasterios riojanos", en Mundos medievales: Espacios, sociedades y poder. Homenaje al profesor José Ángel García de Cortázar y Ruiz de Aguirre, Santander: Universidad de Cantabria, 2012, vol. 2, pp. 1247-1258.

- "El papel de la alta nobleza en el proceso de reforma de los monasterios benedictinos de la Corona de Castilla a fines del Medievo", en Isabel Beceiro Pita (dir.), Poder, piedad y devoción. Castilla y su entorno. Siglos XII-XV, Madrid: Sílex Ediciones, 2014, pp. 359-388.

Dickens, Arthur Geoffrey, The English Reformation, Londres: Fontana Paperbacks, 1967.

Faya Díez, María Ángeles, "La venta de señoríos eclesiásticos de Castilla y León en el siglo XVI", Boletín de la Real Academia de la Historia, 200/2 (2003), pp. 101-32.

García Oro, José, Cisneros y la reforma del clero español en tiempo de los Reyes Católicos, Madrid: CSIC, 1971.

García Oro, José, y Portela Silva, María José, Los monasterios de la Corona de Castilla en el reinado de los Reyes Católicos. Estudio y Colección Diplomática. 1475-1517. Las Congregaciones de la Observancia, Santiago de Compostela: El Eco Franciscano, 2004.

García Turza, Francisco Javier, Documentación Medieval del Monasterio de San Prudencio de Monte Laturce, Logroño: Instituto de Estudios Riojanos, 1991.

Guinea, Demetrio, y Lerena, Tomás, Señores de la guerra, tiranos de sus vasallos. Los duques de Nájera en la Rioja del siglo XVI, Logroño: Editorial Piedra del Rayo, 2006.

Gutiérrez Nieto, Juan Ignacio, Las Comunidades como movimiento antiseñorial, Barcelona: Planeta, 1973.

Jones, Norman, The English Reformation. Religion and Cultural Adaptation, Oxford, Malden (Massachusets): Blackwell, 2002. 
Kamber, Peter, Reformation als bäuerliche Revolution. Bildersturm, Klosterbesetzungen und Kampf gegen die Leibeigenschaft in Zürich zur Zeit der Reformation (1522-1525), Zúrich: Chronos, 2009.

Kaufmann, Thomas, Erlöste und Verdammte. Eine Geschichte der Reformation, Múnich: Beck, 2016.

Lekai, Louis Julius, The Cistercians. Ideals and Reality, Kent: The Kent State University Press, 1977.

Linage Conde, Antonio, San Benito y los benedictinos, Braga: Tipografía Diario do Minho, 1991-1993, 8 vols.

Maldonado, Ramón José, "La Rioja en la Guerra de las Comunidades”, Berceo, 3 (1948), pp. 383-391.

Marcos Pascual, Enrique, Historia y jurisdicción de las abadesas del Monasterio de Cañas en la Edad Media, Logroño: Instituto de Estudios Riojanos, 2016.

Martín, E., Los bernardos españoles. Historia de la Congregación de Castilla de la Orden del Císter, Palencia: Gráf. Aguado, 1953.

Montero Tejada, Rosa María, "Violencia y abusos en los señoríos del linaje Manrique a fines de la Edad Media”, En la España Medieval, 20 (1997), pp. 339-377.

Moxó, Salvador de, "Las desamortizaciones eclesiásticas del siglo XVI", Anuario de Historia del Derecho Español, 31 (1961), pp. 327-361.

Oliva Herrer, Rafael, Justicia contra señores: el mundo rural y la política en tiempos de los Reyes Católicos, Valladolid: Secretariado de Publicaciones de la Universidad de Valladolid, 2004.

Pacheco y de Leyva, Enrique, La política española en Italia. Correspondencia de Don Fernando Marín, abad de Nájera, con Carlos I, Madrid: Junta para Ampliación de Estudios e Investigaciones Científicas. Centro de Estudios Históricos, 1919.

Peña, Joaquín, Páginas Emilianenses, San Millán de la Cogolla: Monasterio de Yuso, 1980, $2^{\mathrm{a}}$. Ed.

Pérez Carazo, Pedro, Santa María de Herce y su abadengo en la Edad Media, Logroño: Instituto de Estudios Riojanos, 2008.

Pérez-Embid Wamba, Francisco Javier, El Císter en Castilla y León. Monacato y dominios rurales (siglos XII-XV), Valladolid: Junta de Castilla y León, 1986.

Reglero de la Fuente, Carlos Manuel, Amigos exigentes, servidores infieles: La crisis de la Orden de Cluny en España (1270-1379), Madrid: CSIC, 2014.

- "Cum reverentia et ceremoniis et honore. Cluny, sus monasterios hispanos y el Capítulo General de 1460", Hispania Sacra, 140 (2017), pp. 533-544.

Rösener, Werner, Reichsabtei Salem. Verfassungs- und Wirtschaftsgeschichte des Zisterzienserklosters von der Gründung bis zur Mitte des 14. Jahrhunderts, Sigmaringa: Jan Thorbecke, 1974.

Rüther, Stephanie, Prestige und Herrschaft. Zur Repräsentation der Lübecker Ratsherren in Mittelalter und Früher Neuzeit, Colonia, Weimar, Viena: Böhlau Verlag, 2003.

Salazar y Castro, Luis de, Historia Genealógica de la Casa de Lara, Madrid: En la Imprenta Real, por Mateo de Llanos y Guzman, 1694-7, 4 vols.

Serrano, Luciano, Cartulario de San Millán de la Cogolla, Madrid: Centro de Estudios Históricos, 1930.

Wunderli, Richard, Peasant Fires. The Drummer of Niklashausen, Bloomington: Indiana University Press, 1992. 